\title{
CFD analysis of forced convective heat transfer coefficients at windward building facades: influence of building geometry
}

\author{
H. Montazeri*,1, B. Blocken ${ }^{1,2}$, D. Derome ${ }^{3,4}$, J. Carmeliet ${ }^{3,4}$, J.L.M. Hensen ${ }^{1}$ \\ ${ }^{1}$ Building Physics and Services, Department of the Built Environment, Eindhoven University of Technology, P.O. box 513, \\ 5600 MB Eindhoven, The Netherlands \\ ${ }^{2}$ Building Physics Section, Department of Civil Engineering, Leuven University, Kasteelpark Arenberg 40 - bus 2447, 3001 \\ Leuven, Belgium \\ ${ }^{3}$ Chair of Building Physics, Swiss Federal Institute of Technology ETHZ, Zurich, Switzerland \\ ${ }^{4}$ Laboratory for Building Science and Technology, Swiss Federal Laboratories for Materials Science and Technology \\ EMPA, Dübendorf, Switzerland
}

\section{CFD analysis of convective heat transfer coefficients: influence of building geometry}
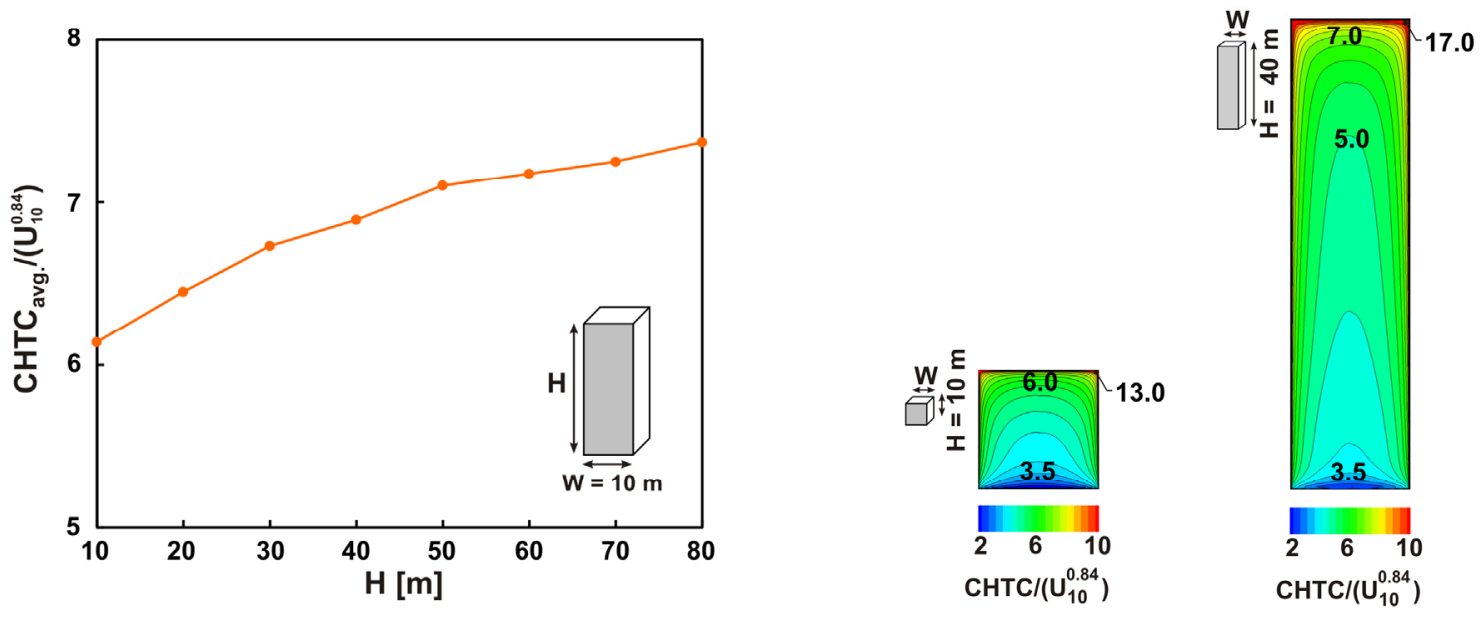

\section{Highlights}

- Influence of building geometry on exterior convective heat transfer coefficients (CHTC).

- A detailed validation study with wind-tunnel measurements.

- Steady RANS indicates satisfactory agreement with experiments for windward surface.

- Surface-averaged $C H T C /\left(U_{10}^{0.84}\right)$ is relatively insensitive to reference wind speed, $\mathrm{U}_{10}$.

- For a constant value of width, by increasing height of building surface-averaged CHTC increases.

- For a constant value of height, by increasing width of building surface-averaged CHTC decreases.

\footnotetext{
* Corresponding author: Hamid Montazeri, Department of the Built Environment, Building Physics and Services, Eindhoven University of Technology, P.O. box 513, 5600 MB Eindhoven, the Netherlands. Tel: +31 (0)40 247 4374, Fax: +31 (0)40 243 8595. E-mail address: h.montazeri@tue.nl
} 


\title{
CFD analysis of forced convective heat transfer coefficients at windward building facades: influence of building geometry
}

\author{
H. Montazeri*,1, B. Blocken ${ }^{1,2}$, D. Derome ${ }^{3,4}$, J. Carmeliet ${ }^{3,4}$, J.L.M. Hensen ${ }^{1}$ \\ ${ }^{1}$ Building Physics and Services, Department of the Built Environment, Eindhoven University of Technology, P.O. box 513, \\ 5600 MB Eindhoven, The Netherlands \\ ${ }^{2}$ Building Physics Section, Department of Civil Engineering, Leuven University, Kasteelpark Arenberg 40 - bus 2447, 3001 \\ Leuven, Belgium \\ ${ }^{3}$ Chair of Building Physics, Swiss Federal Institute of Technology ETHZ, Zurich, Switzerland \\ ${ }^{4}$ Laboratory for Building Science and Technology, Swiss Federal Laboratories for Materials Science and Technology \\ EMPA, Dübendorf, Switzerland
}

\begin{abstract}
Knowledge of the convective heat transfer coefficient (CHTC) for external building surfaces is essential for analysis of building heat gains and losses and hygrothermal analysis of building components. The CHTC is influenced by a wide range of parameters. Previous studies analysed the influence of position on the building facade, roughness, wind speed, wind direction, local airflow pattern and surface-to-air temperature differences. Among methods, Computational Fluid Dynamics (CFD) is a useful tool to determine the distribution of the CHTC across building facades as a function of the governing parameters. However, to the best of our knowledge, research on the influence of building size and geometry on the CHTC is very limited. Therefore this paper presents high-resolution 3D steady Reynolds-averaged Navier-Stokes (RANS) CFD simulations of forced convective heat transfer at the windward facade of 22 buildings of different geometry. First, a CFD validation study focused on CHTC is performed based on wind-tunnel measurements of surface temperature for a reduced-scale wall-mounted cubic obstacle. Next, the influence of building geometry on the CHTC distribution is investigated at different reference wind speeds, $\mathrm{U}_{10}$, for three groups: buildings with $\mathrm{H} \geq \mathrm{W}$, buildings with $\mathrm{H} \leq \mathrm{W}$ and buildings with $\mathrm{H}=\mathrm{W}$. The results show that $\mathrm{CHTC} /\left(\mathrm{U}_{10}^{0.84}\right)$ is relatively insensitive to the reference wind speed. For $\mathrm{W}=10$ $\mathrm{m}$ and by increasing $\mathrm{H}$ from $10 \mathrm{~m}$ to $80 \mathrm{~m}$, the surface-averaged $\mathrm{CHTC} /\left(\mathrm{U}_{10}^{0.84}\right)$ on the windward facade increases by about $20 \%$. However, for $\mathrm{H}=10 \mathrm{~m}$, increasing the building width from 10 to $80 \mathrm{~m}$ has the opposite impact on the surfaceaveraged CHTC/ $\left(\mathrm{U}_{10}^{0.84}\right)$, which decreases by more than $33 \%$. For buildings with $\mathrm{H}=\mathrm{W}$, it decreases by more than $10 \%$ as $\mathrm{H}$ and $\mathrm{W}$ increase from 10 to $40 \mathrm{~m}$, and remains approximately constant for higher values of $\mathrm{H}(=\mathrm{W})$. The reason for these trends are explained.
\end{abstract}

Keywords: Computational Fluid Dynamics (CFD), Validation, building, CHTC, Conjugate heat transfer

\section{Introduction}

Knowledge of the convective heat transfer coefficient (CHTC) at surfaces of bluff bodies immersed in a turbulent boundary layer is essential for a broad range of engineering applications such as electronics cooling [1,2], mist spraying systems [3,4], heat exchangers [5], etc. Similarly, research on building energy and building component durability is dependent on detailed information of the local and mean CHTC. Using inappropriate models to calculate CHTC can lead to considerable errors in Building Energy Simulation (BES). For example, using different correlations shows deviations more than $\pm 30 \%$ in the yearly cooling energy demand and $\pm 14 \%$ in the hourly peak cooling energy demand of an isolated, well-insulated building [6].

The CHTC relates the convective heat flux normal to the wall $\mathrm{q}_{\mathrm{c}, \mathrm{w}}$ to the difference between the surface temperature at the wall, $\mathrm{T}_{\mathrm{w}}$, and a reference temperature, $\mathrm{T}_{\mathrm{ref}}$ :

\footnotetext{
* Corresponding author: Hamid Montazeri, Department of the Built Environment, Building Physics and Services, Eindhoven University of Technology, P.O. box 513, 5600 MB Eindhoven, the Netherlands. Tel: +31 (0)40 247 4374, Fax: +31 (0)40 243 8595. E-mail address: h.montazeri@tue.nl
} 
CHTC $=\frac{\mathrm{q}_{\mathrm{c}, \mathrm{w}}}{\left(\mathrm{T}_{\mathrm{w}}-\mathrm{T}_{\mathrm{ref}}\right)}$

CHTC at the facades of a building is complex and influenced by a wide range of parameters including building geometry, building surroundings, position on the building facade, facade roughness, wind speed, wind direction, local airflow pattern and surface-to-air temperature differences. Therefore, assessing CHTC for buildings is a difficult task. A large number of empirical and semi-empirical correlations between CHTC and the wind speed at a reference location (for example the mean wind speed in the undisturbed flow at a height of $10 \mathrm{~m}$ above the ground, $\mathrm{U}_{10}$ ) has been established. Many of these are implemented in BES programs [6-8] and BE-HAM computational codes [9-13] (BE-HAM = Building Envelope Heat, Air and Moisture transfer). These correlations have been normally derived based on on-site measurements on buildings [14-19] and wind-tunnel experiments [20-22]. However, these on-site measurements were usually performed using heated plates installed on full-scale buildings. In most of these studies, the measurements of CHTC and wind speed (at a distance from the heated surface) were reported only for a limited number of points in space. In addition, a well-known problem of on-site measurements is that there is no or only very limited control over the boundary conditions. This is, however, very important given the wide range of parameters influencing the CHTC, which are not easily varied independently. Reduced-scale wind-tunnel measurements allow a strong degree of control over the boundary conditions. Most of available high-resolution wind-tunnel data used to derive the CHTC correlations are based on the measurements either on flat plates $[20,21]$ or on bluff bodies, mostly cubes, at relatively low Reynolds numbers $\left(10^{3}-10^{4}\right)$ and thin turbulent boundary layers [23-26]. However, the flow structure around buildings is more complex than the one for flat plates. In addition, reduced-scale wind-tunnel measurements at low Reynolds number suffer from the inability to adhere to similarity requirements, which limits the applicability of the available data for building applications $\left(\operatorname{Re} \sim 10^{5}-10^{7}\right)$. Comprehensive reviews on these empirical correlations are presented in Refs. [6,8].

In recent years, CFD has been used in several occasions to investigate the CHTC for buildings, where the influence of wind direction [27], wind speed [27-30] and urban surroundings [31] has been investigated. CFD is a useful tool for performing parametric studies for complex flows [32]. This is especially the case for assessing CHTC as it depends on several physical parameters that are not easily varied independently.

To the best of our knowledge, research on the influence of building geometry on CHTC is very scare and is limited to the experiments by Meroney [33] in which CHTC was examined for three building geometries in a boundary layer windtunnel using infrared camera technique. Indeed, most existing CHTC correlations have been derived or developed for only one specific building geometry, although they are often used for BES simulations of buildings of (very) different geometry, without proper knowledge of the errors introduced by this extrapolation. Therefore, this paper focuses on the influence of building geometry on the CHTC. High-resolution 3D steady RANS CFD simulations of convective heat transfer at the windward facade of several buildings with different geometry are performed to investigate the impact of building geometry on the CHTC. 22 isolated buildings are considered that can be classified into 3 groups of facade geometry: buildings with $\mathrm{H}$ (height) $\geq \mathrm{W}$ (width), buildings with $\mathrm{H} \leq \mathrm{W}$ and buildings with $\mathrm{H}=\mathrm{W}$ (square windward facade). The study is supported by validation with wind-tunnel measurements of surface temperature for a reduced-scale wall-mounted cubic obstacle by Meinders et al. [25,34]. The focus in the present paper is on the windward facade, for several reasons: (1) In BE-HAM programs, the windward facade is the one that is wetted by wind-driven rain and for which knowledge of CHTC and of the related CMTC (convective moisture transfer coefficients) is of particular importance [10,11,35]; (2) the windward facade is the one exposed to the most statistically-stationary (and therefore less complex) wind-flow patterns, which allowed establishing clearer correlations between the CHTC and its influencing parameters in previous studies [1]. The same approach is followed in the present study. It should be noted that, in BES programs, there are two CHTC correlations, one for the windward facade and one for the other, less exposed facades; (3) previous experimental studies indicated that the highest surface-averaged CHTC is obtained for the windward surface of cubic wall-mounted obstacles (e.g. [34]).

It should be noted that there are different ways to define the CHTC as in Eq. (1), using different definitions of the reference temperature. In this paper, all CHTC values are determined based on the upstream (approach-flow) temperature, which is unaffected by the presence of the (heated) surface-mounted obstacle or building. Note that the term "local CHTC" therefore refers to a local value of this parameter based on the approach-flow temperature, not to a local value of this parameter based on a local reference temperature.

This paper contains six sections. In Section 2, the experiments by Meinders et al. [25,34] and the validation study are briefly outlined. Section 3 describes the computational settings and parameters for CFD simulations. Section 4 presents the CFD results. In Section 5, a discussion on the limitations of the study is given. The main conclusions are presented in Section 6. 


\section{CFD validation study}

\subsection{Description of the turbulent channel experiments}

The experiments by Meinders et al. [25,34] are used here for validation purposes. In these experiments, the convective heat transfer at the surfaces of a cube placed in turbulent channel flow was investigated with high resolution. The channel had a height of $0.05 \mathrm{~m}$ and a width of $0.6 \mathrm{~m}$ (Fig. 1a). Two heat exchangers were used to maintain the approach air flow at a constant temperature of $21^{\circ} \mathrm{C}$ with an uncertainty of $\pm 0.5^{\circ} \mathrm{C}[34]$.

The cube had a height $\left(\mathrm{H}_{\mathrm{c}}\right)$ of $0.015 \mathrm{~m}$ resulting in a blockage ratio in the channel of $0.75 \%$. The cube itself had a copper core $\left(12 \times 12 \times 12 \mathrm{~mm}^{3}\right)$ around which an epoxy layer of $0.0015 \mathrm{~m}$ was applied on all surfaces (Fig. $\left.1 \mathrm{~b}\right)$. The copper core was heated at a constant temperature of $75^{\circ} \mathrm{C}$ by a dissipating source (resistance wire) that was placed inside the core. The temperature of the copper core was measured by a thermocouple with an uncertainty of $\pm 0.1^{\circ} \mathrm{C}$. Due to the high thermal conductivity of the copper, a uniformly distributed temperature at the interior of the epoxy layer was obtained. The external surface temperature distribution of the epoxy cube surface when exposed to the wind flow was measured with infrared thermography. The uncertainty of the measured surface temperature using this method was within $\pm 0.4{ }^{\circ} \mathrm{C}$ [34].

The thin layer of epoxy applied on all surfaces of the cube, was used to be able to measure the surface temperature distribution and calculate the surface heat flux in order to evaluate the convective heat transfer coefficients. Meinders et al. $[25,34]$ used the Finite Volume Method to solve the equation for the three-dimensional heat conduction problem for the epoxy layer, given the knowledge of the uniform copper temperature (i.e. $75^{\circ} \mathrm{C}$ ) and surface temperatures (from infrared thermography measurements). A heat balance between the heat conduction (from the inner to the outer epoxy surfaces) and the heat convection (from the outer epoxy surface to the air) yielded the local convective heat transfer coefficient.

The cube was mounted on a base plate with a rather low thermal conductivity of $0.33 \mathrm{~W} / \mathrm{mK}$ to prevent excessive conductive heat losses from the cube to the floor. As the accuracy of the measurements was very sensitive to the epoxy layer thickness, special care was taken to reduce the experimental uncertainties [34]. The layer was machined accurately with an uncertainty of $0.01 \mathrm{~mm}$. The thermal expansion of the epoxy layer was determined experimentally $\left(6.8 \times 10^{-5}{ }^{\circ} \mathrm{C}^{-1}\right)$. To increase the accuracy of the infrared thermography measurements, the external surface of the cube (epoxy layer) was coated with a $0.06 \times 10^{-3} \mathrm{~m}$ layer of black high thermally conductive paint.

Experiments were performed under perpendicular approach flow and for several Reynolds numbers (based on the cube height $\mathrm{H}_{\mathrm{c}}$ ) ranging from 2000 to 5000 . Note that given the relatively low Reynolds numbers in this measurement, it is very likely that all boundary layers over the model are laminar. Earlier wind-tunnel measurements have shown that for such a geometry, turbulent boundary layer is achieved when surface Reynolds numbers exceed about 150,000 [22,33]. In the present study, only the Reynolds number of 4440 is considered. In this condition, the average mass flow rate through the channel was $0.262 \mathrm{~kg} / \mathrm{s}$ per unit area yielding an average bulk velocity $\left(\mathrm{U}_{\infty}\right)$ of $4.47 \mathrm{~m} / \mathrm{s}$.

To generate the turbulent boundary layer flow, tripping strips were used at the bottom of the channel. These strips were located $5 \mathrm{H}$ upstream of the cube. For $\mathrm{Re}=4440$, the resulting vertical profile of mean wind speed for the turbulent boundary layer, at the location where the cube was later placed, was measured and is represented by a $\log \operatorname{law}$ with aerodynamic roughness length $\mathrm{z}_{0}=7.6 \times 10^{-6} \mathrm{~m}$ and a friction velocity $\mathrm{u}^{*}=0.25 \mathrm{~m} / \mathrm{s}$. A developing laminar boundary layer was detected at the ceiling, while the core flow was uniform. The free stream velocity in the channel core, $\mathrm{U}_{\infty}$, was $5.1 \mathrm{~m} / \mathrm{s}$. Laser Doppler Anemometry (LDA) was used to measure the flow field characteristics. The overall experimental uncertainties for the mean velocities and the Reynolds stresses were estimated to be 5\% and $10 \%$, respectively [34].

Meinders et al. [25,34] provided the surface-averaged and cube-averaged CHTC as a function of $\mathrm{Re}_{\mathrm{H}}$, i.e. $\mathrm{CHTC}=\mathrm{A}$ $(\mathrm{Re})^{\mathrm{B}}$. They found exponents between $\mathrm{B}=0.54$ (front face) and $\mathrm{B}=0.67$ (side face), respectively. For the cube-averaged CHTC, the exponent is about 0.65 .

The relative importance of buoyancy effects is assumed negligible as the ratio of the Grashof number to the Reynolds number squared $\left(\mathrm{Gr} / \mathrm{Re}^{2}\right)$ is smaller than 0.3 [34]. Therefore, only forced convection is considered in the simulations.

\subsection{CFD validation: computational domain and grid}

A computational model is made of the cube including the epoxy layer (Fig. 2). The upstream and downstream domain lengths are $4 \mathrm{H}=0.06 \mathrm{~m}$ and $10 \mathrm{H}=0.15 \mathrm{~m}$, respectively. Note that the upstream length is smaller than the one proposed by the guidelines by Franke et al. [36], Tominaga et al. [37] and Blocken [38], i.e. 5H. This limits the appearance of longitudinal gradients in the inlet profiles as mentioned by Blocken et al. $[39,40]$. The domain height is chosen equal to that of the channel in the experiments $(=3.3 \mathrm{H})$ (Fig. 1a). It should be noted that the vicinity of the channel ceiling to the cube might cause an artificial acceleration of the flow over the top surface and a suppression of turbulence [25,34]. These phenomena can affect the heat transfer process in the flow especially at the top of the cube [34]. The distance between the cube walls and the lateral planes of the domain is $10 \mathrm{H}=0.15 \mathrm{~m}$, resulting in a blockage ratio of $1.4 \%$. This ratio, like the 
experimental value, is well below the maximum blockage ratio of $3 \%$ recommended by the aforementioned CFD best practice guidelines [36-38].

The computational grid is generated with the aid of the pre-processor Gambit 2.4.6 using the surface-grid extrusion technique [41]. A total number of 40 cells with a uniform grid spacing (i.e. stretching ratio $=1$ ) is applied along the cube surfaces in $x-$, $y$ - and z-directions (with 4 cells across the epoxy layer thickness) (Fig. 3). These cubical cells extend up to a distance of $\mathrm{H} / 3$ from the cube surfaces. Beyond this distance, a stretching factor of 1.05 is applied, to limit the total number of cells. This resulted in a fully structured grid with 2,180,960 hexahedral cells. The grid resolution resulted from a gridsensitivity analysis (not shown in this paper). The minimum and maximum cell volumes in the domain are approximately 5 $\times 10^{-11} \mathrm{~m}^{3}$ and $2 \times 10^{-7} \mathrm{~m}^{3}$, respectively. The distance from the centre point of the wall adjacent cell to the wall is $\mathrm{yp}_{\mathrm{P}}=3 \times$ $10^{-4} \mathrm{~m}$, corresponding to an average $y^{*}$ value of 3.8 over the cube surfaces. The maximum $y^{*}$ value of 6.9 only occurs at the top corners of the windward surface.

\subsection{CFD validation: boundary conditions}

Planes 1 and 3 in Fig. 2a are the inlet and outlet planes, while planes 2 and 4 are the side planes. The inlet velocity profile needed for the CFD simulations is not given in Ref. [25]. However, knowledge of this profile is essential for accurate CFD simulations. From the experiments, the measured mass flow rate in the channel $\dot{\mathrm{m}}_{\mathrm{t}}=0.262 \mathrm{~kg} / \mathrm{s}$ per unit area $(\operatorname{Re}=4440)$ is known. Based on this information, we determined the profile as follows. We considered a three-part profile (Fig. 4a): a turbulent boundary layer (part 1), a uniform core flow (part 2) and a laminar boundary layer (part 3) near the top wall as pointed out by Meinders et al. [25,34]. The air velocity in the turbulent boundary layer varies from zero close to the floor, to $\mathrm{U}_{\infty}=5.1 \mathrm{~m} / \mathrm{s}$ at $\mathrm{H}_{1}=1.53 \mathrm{H}$. The uniform velocity of the second regime is equal to $\mathrm{U}_{\infty}$. The laminar boundary layer velocity profile is given by [42]:

$\frac{\mathrm{u}_{3}}{\mathrm{U}_{\infty}}=\left[2\left(\frac{\mathrm{z}}{\mathrm{H}_{3}}\right)-\left(\frac{\mathrm{z}}{\mathrm{H}_{3}}\right)^{2}\right]$

where $\mathrm{H}_{3}$ is the laminar boundary layer thickness. To determine the velocity profile, $\mathrm{H}_{2}$ or $\mathrm{H}_{3}$, the heights of the second and third parts of the profile need to be determined. The air mass flow rate of each part can be calculated based on its average velocity $\left(\rho \bar{u}_{i} H_{i}\right)$. Note that the average velocity of the laminar boundary layer is $2 / 3\left(\mathrm{U}_{\infty}\right)$. Conservation of mass in a plane perpendicular to the flow direction yields: $\dot{\mathrm{m}}_{1}+\dot{\mathrm{m}}_{2}+\dot{\mathrm{m}}_{3}=\dot{\mathrm{m}}_{\mathrm{t}}$. The results are shown in Fig. $4 \mathrm{~b}$ (solid line). Fig. $4 \mathrm{c}$ shows the measured (dots) and fitted profile of the turbulent kinetic energy $\mathrm{k}$. The appearance of longitudinal gradients is analysed by comparing the vertical profiles of the stream-wise velocity, $\mathrm{u}$, and turbulent kinetic energy, $\mathrm{k}$, profiles at the lateral edge of the domain (i.e. at $8 \mathrm{H}$ from the lateral side of the cube) where the flow is undisturbed by the presence of the cube. Fig. 5 compares the profiles at $\mathrm{x}=0$ (inlet) and $\mathrm{x}=4 \mathrm{H}$ (cube position). The average deviation from the prescribed inlet values of $\mathrm{U}$ is about $2 \%$. For $\mathrm{k}$, however, this deviation is more pronounced along the line, especially close to the ground plane $(\mathrm{z} / \mathrm{H}=$ 0.17 ) where it reaches $50 \%$. This will be a factor contributing to possible discrepancies between simulations and experiments, especially near the bottom of the domain, as also shown in a previous publication [39]. The turbulence dissipation rate $\varepsilon$ is given by Eq. (3), with $\kappa$ the von Karman constant $(=0.42)$.

$\varepsilon(\mathrm{z})=\frac{\mathrm{u}^{* 3}}{\kappa\left(\mathrm{z}+\mathrm{z}_{0}\right)}$

Zero static pressure is applied at the outlet plane. Symmetry conditions, i.e. zero normal velocity and zero normal gradients of all variables, are applied at the lateral sides of the domain. The ground and top of the domain are defined as noslip smooth walls.

The thermal boundary conditions are a uniform inlet air temperature of $294 \mathrm{~K}\left(21^{\circ} \mathrm{C}\right)$ and a fixed surface temperature of $348 \mathrm{~K}\left(75^{\circ} \mathrm{C}\right)$ for the inner surface of the epoxy layer (plane 6 in Fig. $\left.2 b\right)$. To couple the two zones on the solid/fluid interface (plane 5 in Fig. 2b), heat transfer is calculated directly from the solution of temperature in the adjacent cells of the fluid (air) and solid (epoxy layer). For the bottom of the epoxy layer (plane 7 in Fig. 2b), the average value of the surface temperature of the windward surface close to the ground plane $(\mathrm{H} / 65)$ and the copper core is used. The bottom and top surfaces of the computational domain are adiabatic walls. 


\subsection{CFD validation: solver settings}

The 3D steady RANS equations are solved with the commercial CFD code Ansys/Fluent 12.1 [43]. The realizable k- $\varepsilon$ model (Rk-E) [44] in combination with the low-Re number Wolfshtein model [45] is used for closure. The SIMPLE algorithm is used for pressure-velocity coupling, pressure interpolation is second order and second-order discretization schemes are used for both the convection terms and the viscous terms of the governing equations. Convergence is assumed when all the scaled residuals level off and reach the values $10^{-7}$ for $\mathrm{x}, \mathrm{y}, \mathrm{z}$ momentum and energy, $10^{-5}$ for continuity and $10^{-6}$ for $\mathrm{k}$ and $\varepsilon$.

\subsection{CFD validation: results}

Figs. 6a and c compare the experimental and CFD results of surface temperature along lines at the intersection of the cube with a central vertical plane and a mid-height horizontal plane. The differences between measurements and simulations, averaged along the windward, top, side and leeward lines, are given in Figs. $6 \mathrm{~b}$ and d. For the windward surface, the general agreement is good with average deviations of about 1.7 and $2.4 \%$ along the vertical and horizontal lines, respectively, although a small overestimation of the maximum local surface temperature can be observed close to the ground (Fig. 6a). The main reasons for this can be: (1) the additional heat loss of the epoxy layer through the base wall in the experiments, which is not taken into account in the simulations (Fig. 1b) and/or (2) incorrect prediction of the size and shape of the standing vortex due to the upstream longitudinal gradients in the approach-flow profiles (Fig. 5) [39,40]. For the top and side surfaces of the cube, the agreement is not good and the average deviations increase to more than 6.5 and $6.6 \%$. As the local heat transfer at the surfaces of the cube is highly dependent on the complex intermittent flow structure around the obstacle, the deviations in temperature of these surfaces can be directly related to the inaccurate flow field prediction by steady RANS downstream of the windward facade. It is well-known that steady RANS is incapable of capturing the inherently transient behavior of separation, reattachment and recirculation downstream of the windward surface and of von Karman vortex shedding in the wake [32,46-48]. Nevertheless, for the leeward surface, CFD shows a good performance along the horizontal line, especially in the middle of the line. Close to the side edges, however, the temperatures are overestimated. A large overestimation can also clearly be observed close to the upper edge of the leeward surface (along the vertical line). However, as the focus in this paper is on the windward façade, where very good agreement is found, the computational settings and parameters used in the validation study will continue to be used in the remainder of this paper.

\section{CFD simulation}

\subsection{List of cases}

In this study, 22 isolated buildings are considered. The buildings can be classified into 3 groups (Table 1):

Buildings with $\mathrm{H} \geq \mathrm{W}(\mathrm{W}=10 \mathrm{~m}$ and $10 \mathrm{~m} \leq \mathrm{H} \leq 80 \mathrm{~m})$;

Buildings with $\mathrm{H} \leq \mathrm{W}(\mathrm{H}=10 \mathrm{~m}$ and $10 \mathrm{~m} \leq \mathrm{W} \leq 80 \mathrm{~m})$;

Buildings with $\mathrm{H}=\mathrm{W}(10 \mathrm{~m} \leq \mathrm{H}=\mathrm{W} \leq 80 \mathrm{~m})$

Note that the depth of all buildings is identical $\mathrm{D}=20 \mathrm{~m}$.

\subsection{Computational geometry and grid}

The dimensions of the computational domains are chosen based on the best practice guidelines by Franke et al. [36] and Tominaga et al. [37]. The upstream and downstream domain length are $5 \mathrm{H}$ and $15 \mathrm{H}$, respectively. Note that the upstream length is not reduced to $4 \mathrm{H}$ as in the validation study, because in this section, consistency between inlet profiles, wall functions, ground roughness, turbulence model and computational grid is achieved by combining the guidelines by Richards and Hoxey [49] and Blocken et al. [40]. High-resolution hybrid grids with about $2 \times 10^{6}$ prismatic and hexahedral cells is generated using the surface-grid extrusion technique [41]. In this case, $\mathrm{y}_{\mathrm{p}}$, the distance from the centre point of the walladjacent cell to the wall, is about $400 \mu \mathrm{m}$. Note that due to higher Re numbers for the full-scale buildings, the $\mathrm{y}_{\mathrm{p}}$ is smaller than the one used for the cube in the validation study. The maximum $y^{*}$ value is below 5 for all simulations, which is essential for accurate and reliable CFD simulations of near-wall heat transfer [27,29].

\subsection{Boundary conditions}

At the inlet of the domain, neutral atmospheric boundary layer inflow profiles of mean wind speed $U(\mathrm{~m} / \mathrm{s})($ Eq. 4), turbulent kinetic energy k $\left(\mathrm{m}^{2} / \mathrm{s}^{2}\right)$ (Eq. 5) and turbulence dissipation rate $\varepsilon\left(\mathrm{m}^{2} / \mathrm{s}^{3}\right)($ Eq. 3) are imposed [49]. 
$\mathrm{U}(\mathrm{z})=\frac{\mathrm{u}_{\mathrm{ABL}}^{*}}{\kappa} \ln \left(\frac{\mathrm{z}+\mathrm{z}_{0}}{\mathrm{z}_{0}}\right)$

$\mathrm{k}(\mathrm{z})=3.3 \mathrm{u}_{\mathrm{ABL}}^{*}{ }^{2}$

It is assumed that the buildings are situated on a large grass-covered terrain with an aerodynamic roughness length $\mathrm{z}_{0}=$ $0.03 \mathrm{~m}$ [50]. Five reference wind speeds at $10 \mathrm{~m}$ height are used $\mathrm{U}_{10}=1,2,3,4$ and $5 \mathrm{~m} / \mathrm{s}$. It yields building Reynolds numbers ranging from $0.7 \times 10^{6}$ to $28 \times 10^{6}$ based on the height of the buildings $(\mathrm{H})$, making the boundary layer safely turbulent over most of their surfaces. Zero static pressure is applied at the outlet plane. Symmetry conditions are applied at the top and lateral sides of the domain. The ground surface is modelled as a no-slip wall with zero roughness height $\mathrm{k}_{\mathrm{s}}=0$, since in LRNM surface roughness values cannot be specified [27].

The thermal boundary conditions are a uniform inlet air temperature of $\mathrm{T}_{\text {ref }}=10{ }^{\circ} \mathrm{C}$ and a fixed surface temperature of $\mathrm{T}_{\mathrm{w}}=30^{\circ} \mathrm{C}$ for the building surfaces. The adiabatic boundary condition is used for the ground surface.

\subsection{Solver settings}

The solver settings are identical to those used in the validation study and reported in Sec 2.4. The 3D steady RANS equations with the realizable $k-\varepsilon$ turbulence model are solved in combination with the low-Re number Wolfshtein model [45]. Only forced convection is considered in the simulations.

\section{Results}

\subsection{Correlation between $C H T C$ and $U_{I 0}$}

To obtain correlations between the CHTC, averaged over the entire windward facade, and $\mathrm{U}_{10}$, the approach-flow mean wind speed at $10 \mathrm{~m}$ height, simulations with five different reference wind speed values are used: $U_{10}=1,2,3,4$ and $5 \mathrm{~m} / \mathrm{s}$. The simulations are performed for all eight buildings with $\mathrm{H} \leq \mathrm{W}(\mathrm{W}=10-80 \mathrm{~m})$, for three of the buildings with $\mathrm{H} \geq \mathrm{W}$ $(\mathrm{H}=10,20$ and $30 \mathrm{~m})$ and for three of the buildings with $\mathrm{H}=\mathrm{W}(\mathrm{H}=\mathrm{W}=10,20$ and $30 \mathrm{~m})$. Choosing this set of buildings ensures that the maximum $\mathrm{y}^{*}$ remains below 5 for the highest reference wind speed value. Figs. $7 \mathrm{a}, \mathrm{c}$ and e show the relationship between the surface-averaged CHTC and $\mathrm{U}_{10}$ for the three groups of buildings. Power-law correlations are derived with high coefficients of determination $\left(\mathrm{R}^{2}\right)$, as shown in Table 2 . The exponents in all correlations are very close, ranging from 0.82 to 0.87 , with a maximum deviation of about $5 \%$. In addition, these exponents are comparable to those found in previous CFD studies, provided in Table 3. In spite of small differences in the exponents, the correlations presented in Tables 2 and 3 might lead to different values of surface-averaged CHTC, given that the inlet boundary conditions and building geometry in these studies are different.

Given the fact that the exponents in all correlations in Table 2 are quite similar for the different reference wind speed values, one can expect that the variable $\mathrm{CHTC} /\left(\mathrm{U}_{10}^{0.84}\right)$ is relatively insensitive to $\mathrm{U}_{10}$ for each building geometry. The exponent 0.84 is chosen as the average value of the minimum and maximum values in the range. Figs. $7 \mathrm{~b}, \mathrm{~d}$ and $\mathrm{f}$ displays the variations of $\mathrm{CHTC} /\left(\mathrm{U}_{10}^{0.84}\right)$ as a function of $\mathrm{U}_{10}$ for different building geometry. The value of $\mathrm{CHTC} /\left(\mathrm{U}_{10}^{0.84}\right)$ is almost constant with $\mathrm{U}_{10}$. The fact that $\mathrm{CHTC} /\left(\mathrm{U}_{10}^{0.84}\right)$ is nearly constant suggests that the building boundary layers are predominately turbulent during the CFD simulations, since it has long been known that $N U /\left(\mathrm{Re}^{0.84}\right)$ correlates most turbulent boundary layer heat transfer behaviour. The fact that the exponent is slightly different from 0.8 is probably due to the fact that for the windward walls the flow is essentially in stagnation up the facade centerline and develops laterally and vertically outward from the center to the edges of the building. The flow over the windward facade is nominally only parallel to the surface as one moves toward the edges. There is also a spacewise variation in the velocities at the top of the building boundary layers since the local edge of the boundary layer velocity parallel to the surface would increase close to the building corners. This is an important observation, especially from the viewpoint of computational economy. Indeed, because as the value of $U_{10}$ increases, the thickness of the laminar sublayer decreases [27]. Because accurately calculating the CHTC with CFD requires that at least a few cells are placed inside the laminar sublayer, an increasing value of $\mathrm{U}_{10}$ implies ever smaller values of $\mathrm{y}^{*}$ and an increase in the total number of cells. The observation that $\mathrm{CHTC} /\left(\mathrm{U}_{10}^{0.84}\right)$ is independent of $U_{10}$ however allows us to only perform the CFD simulations for a low value of $U_{10}$, say $1 \mathrm{~m} / \mathrm{s}$, in order to obtain the CHTC at this and also all other values of $U_{10}$. Therefore, in the remainder of this paper, all results shown were obtained by CFD simulations with $\mathrm{U}_{10}=1 \mathrm{~m} / \mathrm{s}$, but they will be presented as hat $\mathrm{CHTC} /\left(\mathrm{U}_{10}^{0.84}\right)$ to indicate their general character. 


\subsection{Influence of building geometry on CHTC}

In this section, the influence of building geometry on CHTC at the windward facade of the buildings (Table 1) is investigated. The results are presented at $U_{10}=1 \mathrm{~m} / \mathrm{s}$ and for all buildings presented in Table 1 .

\subsubsection{Buildings with $H \geq W$}

The local and surface-averaged CHTC at the surfaces of a bluff body is highly dependent on the immediate flow structure around the obstacle $[1,2]$. Therefore, for the three groups of buildings, the wind speed distribution near the windward facade is initially presented. Fig. 8 shows the normalized wind speed distribution across a vertical plane at a distance $d=0.3 \mathrm{~m}$ from the windward facade of three buildings, i.e. those with $\mathrm{H}=10,40$ and $70 \mathrm{~m}$. Taking the plane at this distance is inspired by that used in some full-scale measurements e.g. [14]. A region with low wind speed is observed in the upper part of each plane near the position of the stagnation point on the windward facade. The position of the stagnation point depends on the height of the buildings (not shown in this figure). For the three cases with $\mathrm{H}=10,40$ and $70 \mathrm{~m}$, for example, the stagnation point is located at $0.53 \mathrm{H}, 0.72 \mathrm{H}$ and $0.77 \mathrm{H}$ from ground level, respectively. The stagnation pressure forces the impinging wind flow to deviate towards the top and side edges, which leads to higher wind speed near these edges. Note that, by increasing the height of the buildings, the wind speed at the edges also increases. Close to the base of the buildings, where the dominant flow feature is the horseshoe vortex, a region with a low wind speed can also be seen. A closer look at Fig. 8 reveals that the height of the horseshoe vortex is relatively independent of the building height.

The CHTC/ $\left(\mathrm{U}_{10}^{0.84}\right)$ distribution across the windward facade of the three buildings with $\mathrm{H}=10,40$ and $70 \mathrm{~m}$ is shown in Fig. 9. The distributions are compared with the wind speed distributions shown in Fig. 8. The maximum CHTC values occur at the top and lateral edges where the wind speed is relatively high. Therefore, by increasing the height of the buildings, the maximum $\mathrm{CHTC} /\left(\mathrm{U}_{10}^{0.84}\right)$ values also increase. From this figure, a relatively uniform $\mathrm{CHTC} /\left(\mathrm{U}_{10}^{0.84}\right)$ distribution is observed over the central part of the facade. This corresponds to the uniform high-pressure [51] and low-velocity (Fig. 8) zones in this part of the facade. In the lower part of the facade, near the region where the horseshoe vortex occurs, the local $\mathrm{CHTC} /\left(\mathrm{U}_{10}^{0.84}\right)$ is relatively low. This is due to the rotational behavior of the vortex, which increases the residence time of the air in this region leading to an increase in the local air temperature and a reduction in the local value of $\mathrm{CHTC} /\left(\mathrm{U}_{10}^{0.84}\right)$. The height and position of this region is the same for the three cases.

Fig. 10 shows the profile of the surface-averaged CHTC $/\left(\mathrm{U}_{10}^{0.84}\right)$ on the windward facade for different values of $\mathrm{H}$. It can be seen that for a given building width $(\mathrm{W}=10 \mathrm{~m})$ and depth $(\mathrm{D}=20 \mathrm{~m})$, an increase in $\mathrm{H}$ from $10 \mathrm{~m}$ to $80 \mathrm{~m}$ increases the surface-averaged CHTC/ $\left(\mathrm{U}_{10}^{0.84}\right)$ by about $20 \%$.

\subsubsection{Buildings with $W \geq H$}

Fig. 11 displays the normalized wind speed distribution across a vertical plane near the windward facade $(\mathrm{d}=0.3 \mathrm{~m})$ of the buildings with $\mathrm{W}=10,40$ and $70 \mathrm{~m}$. Increasing the width of the buildings results in a more pronounced wind-blocking effect upstream of the building. The wind-blocking effect $[39,52]$ is defined as the disturbance of the wind-flow pattern due to the presence of the building and the associated decrease of the upstream stream-wise wind-velocity component (windspeed slow-down). Thus, increasing the width of the buildings results in a reduced wind speed near the building facade. This reduction is more pronounced in the central part of the plane. For the top and lateral edges, the local wind speed values are almost the same in all cases.

The CHTC $/\left(\mathrm{U}_{10}^{0.84}\right)$ distributions across the windward facade of the three buildings are presented in Fig. 12. By increasing the width of the buildings, the local $\mathrm{CHTC} /\left(\mathrm{U}_{10}^{0.84}\right)$ in the central portion of the facade is reduced. This is consistent with the wind speed reduction near the windward facades, as explained in section 4.2.1. In addition, a reduction is also seen at the top and lateral edges of the buildings, where the local wind velocity is relatively independent of the building width (Fig. 11). The main reason for this reduction is the increase in time that the air is in contact with the facade. Due to the longer contact time, the temperature difference between the air and the surface reduces and this leads to a decrease in the local CHTC/ $\left(\mathrm{U}_{10}^{0.84}\right)$. Note that the time, during which the convective heat transfer occurs between the air and the facade (length along streamline) is most likely related to the dimension of the facade and wind speed.

The profile of the surface-averaged CHTC/ $\left(\mathrm{U}_{10}^{0.84}\right)$ on the windward facade for different values of building width, W, is presented in Fig. 13. The surface-averaged CHTC/ $\left(\mathrm{U}_{10}^{0.84}\right)$ decreases monotonically by increasing the width of the buildings. For a given height, $\mathrm{H}=10 \mathrm{~m}$, as $\mathrm{W}$ increases from 10 to $80 \mathrm{~m}$, the surface-averaged $\mathrm{CHTC} /\left(\mathrm{U}_{10}^{0.84}\right)$ decreases by more than $33 \%$. 


\subsubsection{Buildings with $W=H$}

Fig. 14 presents the normalized wind speed distribution across a vertical plane at a distance $d=0.3 \mathrm{~m}$ from the windward facade of the three buildings with $\mathrm{H}=\mathrm{W}=10,40$ and $70 \mathrm{~m}$. By increasing the building dimensions, the local wind speed also increases especially near the top and lateral edges.

Fig. 15 shows the $\mathrm{CHTC} /\left(\mathrm{U}_{10}^{0.84}\right)$ distribution on the windward facade of the three buildings. A reduction in the local CHTC/ $\left(\mathrm{U}_{10}^{0.84}\right)$ values is observed on the entire facade by increasing the $\mathrm{H}$ and $\mathrm{W}$ from 10 to $40 \mathrm{~m}$. Such reduction is most pronounced near the top and lateral edges. By increasing $\mathrm{H}$ and $\mathrm{W}$ from 40 to $70 \mathrm{~m}$, however, the distribution remains nearly identical. To understand this constant behaviour, the variations in the air speed and air temperature distributions near the windward facades is examined. Fig. 16 displays the profiles of normalized air temperature $\left(T-T_{w}\right) /\left(T_{r e f}-T_{w}\right)$ along two lines at a distance $\mathrm{d}=0.3 \mathrm{~m}$ from the windward facade. By increasing $\mathrm{H}$ and $\mathrm{W}$, the temperature difference between the air and the surface decreases. This is related to the increase in the contact time between the air and the surface especially at the top and lateral edges. Note that the wind speed and the temperature difference between the air and the surface have opposite effects on the rate of convective heat transfer. Figs. 14 and 16 show that as $\mathrm{H}$ and $\mathrm{W}$ increase from 10 to $40 \mathrm{~m}$, the decrease in the temperature difference between the air and the surface has a dominant impact of the local $\mathrm{CHTC} /\left(\mathrm{U}_{10}^{0.84}\right)$ rather than the impact of the increase in the wind speed (Fig. 14). On the other hand, as $\mathrm{H}$ and $\mathrm{W}$ increase from 40 to $70 \mathrm{~m}$, however, the two effects counterbalance each other leading to the relatively similar $\mathrm{CHTC} /\left(\mathrm{U}_{10}^{0.84}\right)$ distributions.

The profile of the surface-averaged $\mathrm{CHTC} /\left(\mathrm{U}_{10}^{0.84}\right)$ as a function of building dimensions is shown in Fig 17. By increasing the height (width) of the buildings from $10 \mathrm{~m}$ to $40 \mathrm{~m}$, the surface-averaged CHTC decreases by $10 \%$. Further increase in $\mathrm{H}(=\mathrm{W})$ from 40 to $80 \mathrm{~m}$, leads to an opposite trend in the surface-averaged $\mathrm{CHTC} /\left(\mathrm{U}_{10}^{0.84}\right)$. In this case, the surface-averaged $\mathrm{CHTC} /\left(\mathrm{U}_{10}^{0.84}\right)$ slightly increases, by $3 \%$.

\section{Discussion}

This work was motivated by lack of knowledge on the impact of building size and geometry on the local and mean CHTC.

In this study, the CFD validation is performed for a wall-mounted cube in a turbulent flow at an obstacle Re number of 4440. Such choice is due to the lack of available high-resolution wind-tunnel data of CHTC at realistic Reynolds numbers for building applications $\left(\sim 10^{5}-10^{7}\right)$. Given the relatively low Reynolds number in the measurements, it is very likely that all boundary layers over the model are laminar. Therefore, further CFD validation studies are required at sufficiently high Reynolds numbers to ensure the turbulent boundary layer is obtained.

The focus of this study is on the surface-averaged CHTC. Research however shows that the complex wind flow around a wall-mounted cubic obstacle results in highly varying CHTC values across its surfaces. In this case, the local values deviate significantly from average values especially in regions of stagnation, separation and reattachment $[25,27,33]$.

The focus of this paper is on the windward facade. Further research is needed to investigate the CHTC distributions for facades other than the windward façade. Note however that steady RANS is incapable of capturing the inherently transient behaviour of separation and recirculation downstream of the windward facade and of von Karman vortex shedding in the wake. Therefore, (more) accurate results at these surfaces should be pursued using transient simulations with DES or LES.

This study is only performed for single isolated and simplified buildings. Future CFD studies should focus on different building configurations in different environment topographies. Note that in many European cities, high-rise buildings are generally positioned among low-rise buildings, and not present in groups/clusters, as in more modern cities on the American continent. Therefore, they can to some extent be represented by an isolated building in this theoretical study.

In this study, the simulations are performed for smooth and simple facades. Future work will take into account the impact of surface roughness on CHTC. Such roughness should include small-scale facade roughness, related to the building materials, and large-scale facade roughness, related to the building details like window openings and balconies. Earlier experiments have shown the importance of small-scale roughness on convective heat transfer [15]. The large-scale facade roughness, such as balconies, can lead to very strong changes in wind field around the building [51,53], which can affect the CHTC distribution considerably.

\section{Conclusions}

This paper focuses on the influence of building size and geometry on the CHTC. High-resolution 3D steady RANS CFD simulations of convective heat transfer at the facades of several buildings with different size and geometry are performed to investigate the impact of building geometry on CHTC. 22 isolated buildings are considered that can be classified into 3 groups: buildings with $\mathrm{H}$ (height) $\geq \mathrm{W}$ (width), buildings with $\mathrm{H} \leq \mathrm{W}$ and buildings with $\mathrm{H}=\mathrm{W}$ (square windward facade). The evaluation is based on validation with wind-tunnel measurements of surface temperature for a reduced-scale wallmounted cubic obstacle. The results of the CFD validation shows that the high-Re number realizable $\mathrm{k}-\varepsilon$ model in 
combination with the low-Re number Wolfhstein model can provide accurate results for convective heat transfer at the windward surface of reduced-scale cubic models.

Based on the low-Re number CFD simulations for buildings with different geometry, the following conclusions are made:

- $\quad \mathrm{CHTC} /\left(\mathrm{U}_{10}^{0.84}\right)$ is relatively insensitive to the reference wind speed, $\mathrm{U}_{10}$.

- For $\mathrm{W}=10 \mathrm{~m}$ and by increasing $\mathrm{H}$ from $10 \mathrm{~m}$ to $80 \mathrm{~m}$, the surface-averaged CHTC/ $\left(\mathrm{U}_{10}^{0.84}\right)$ on the windward facade increases by about $20 \%$. Such increase is related to the increase in the local wind speed values at the lateral and top edges of the windward façade with increasing building height.

- For $\mathrm{H}=10 \mathrm{~m}$, increasing the building width from 10 to $80 \mathrm{~m}$ has the opposite impact on the surface-averaged CHTC $/\left(\mathrm{U}_{10}^{0.84}\right)$, which decreases by more than $33 \%$. This reduction is related to the wind-blocking effect (windspeed slow-down) upstream of the buildings, which is more pronounced for wider buildings. In this case, the time that the air is in contact with the facade increases which reduces the temperature difference between the air and the surface leading to a decrease in the local CHTC $/\left(\mathrm{U}_{10}^{0.84}\right)$.

- For buildings with $\mathrm{H}=\mathrm{W}$, increasing the building height and width from $10 \mathrm{~m}$ to $40 \mathrm{~m}$ yields a $10 \%$ reduction in the surface-averaged $\mathrm{CHTC} /\left(\mathrm{U}_{10}^{0.84}\right)$ on the windward facade. For higher values of $\mathrm{H}$ and $\mathrm{W}$, however, the opposite trend is found with a slight increase of $3 \%$. This trend can be explained as the combination of the individual impact of building width and building height on $\mathrm{CHTC} /\left(\mathrm{U}_{10}^{0.84}\right)$.

\section{Acknowledgements}

This research was supported by the Dutch Knowledge for Climate Research Program within the theme Climate Proof Cities (CPC). The authors also acknowledge their colleagues Dr. E.R. Meinders and Prof. K. Hanjalić who have published the very valuable experimental data that was used for the validation study in the present paper.

\section{References}

[1] Ničeno B, Dronkers AD., Hanjalić K. Turbulent heat transfer from a multi-layered wall-mounted cube matrix: a large eddy simulation. Int J Heat Fluid Flow 2002;23:173-85. doi:10.1016/S0142-727X(01)00147-3.

[2] Popovac M, Hanjalić K. Vortices and heat flux around a wall-mounted cube cooled simultaneously by a jet and a crossflow. Int J Heat Mass Transf 2009;52:4047-62.

[3] Montazeri H, Blocken B, Hensen JL. CFD analysis of the impact of physical parameters on evaporative cooling by a mist spray system. Appl Therm Eng 2015;75:608-22.

[4] Montazeri H, Blocken B, Hensen JLM. Evaporative cooling by water spray systems: CFD simulation, experimental validation and sensitivity analysis. Build Environ 2015;83:129-41.

[5] Iacovides H, Launder BE. Computational fluid dynamics applied to internal gas-turbine blade cooling: a review. Int J Heat Fluid Flow 1995;16:454-70.

[6] Mirsadeghi M, Cóstola D, Blocken B, Hensen JLM. Review of external convective heat transfer coefficient models in building energy simulation programs: implementation and uncertainty. Appl Therm Eng 2013;56:134-51.

[7] Crawley DB, Hand JW, Kummert M, Griffith BT. Contrasting the capabilities of building energy performance simulation programs. Build Environ 2008;43:661-73.

[8] Palyvos JA. A survey of wind convection coefficient correlations for building envelope energy systems' modeling. Appl Therm Eng 2008;28:801-8.

[9] Hens HS. Heat, Air and Moisture Transfer in Insulated Envelope Parts: Task 1, Modelling, Final Report. Acco, Leuven; 1996.

[10] Künzel HM, Kiessl K. Calculation of heat and moisture transfer in exposed building components. Int J Heat Mass Transf 1996;40:159-67.

[11] Janssen H, Blocken B, Carmeliet J. Conservative modelling of the moisture and heat transfer in building components under atmospheric excitation. Int J Heat Mass Transf 2007;50:1128-40.

[12] Hall C, Hoff WD. Water transport in brick, stone and concrete. CRC Press; 2011.

[13] Hens HS. Building Physics-Heat, Air and Moisture: Fundamentals and Engineering Methods with Examplesand Exercises. John Wiley \& Sons; 2012.

[14] Ito N, Kimura K, Oka J. Field experiment study on the convective heat transfer coefficient on exterior surface of a building. ASHRAE Trans 1972;78:184-92.

[15] Cole RJ, Sturrock NS. The convective heat exchange at the external surface of buildings. Build Environ 1977;12:20714. 
[16] Sharples S. Full-scale measurements of convective energy losses from exterior building surfaces. Build Environ 1984;19:31-9.

[17] Loveday DL, Taki AH. Convective heat transfer coefficients at a plane surface on a full-scale building facade. Int J Heat Mass Transf 1996;39:1729-42.

[18] Jayamaha SEG, Wijeysundera NE, Chou SK. Measurement of the heat transfer coefficient for walls. Build Environ 1996;31:399-407.

[19] Liu Y, Harris DJ. Full-scale measurements of convective coefficient on external surface of a low-rise building in sheltered conditions. Build Environ 2007;42:2718-36.

[20] Jürges W. Der Wärmeübergang an einer ebenen Wand. Druck und Verlag von R. Oldenbourg; 1924.

[21] Sparrow EM, Ramsey JW, Mass EA. Effect of finite width on heat transfer and fluid flow about an inclined rectangular plate. J Heat Transf 1979;101:199-204.

[22] Kelnhofer WJ, Thomas CJ. External convective heat transfer coefficients on a building model, ASME Publication, 76WA/FE-30, August 12; 1976.

[23] Chyu MK, Natarajan V. Local heat/mass transfer distributions on the surface of a wall-mounted cube. Trans ASME J Heat Transf 1991;113:851-7.

[24] Natarajan V, Chyu MK. Effect of flow angle-of-attack on the local heat/mass transfer from a wall-mounted cube. Trans ASME J Heat Transf 1994;116:552-60.

[25] Meinders ER, Hanjalic K, Martinuzzi RJ. Experimental study of the local convection heat transfer from a wallmounted cube in turbulent channel flow. Trans ASME J Heat Transf 1999;121:564-73.

[26] Nakamura H, Igarashi T, Tsutsui T. Local heat transfer around a wall-mounted cube in the turbulent boundary layer. Int J Heat Mass Transf 2001;44:3385-95.

[27] Blocken B, Defraeye T, Derome D, Carmeliet J. High-resolution CFD simulations for forced convective heat transfer coefficients at the facade of a low-rise building. Build Environ 2009;44:2396-412.

[28] Emmel MG, Abadie MO, Mendes N. New external convective heat transfer coefficient correlations for isolated lowrise buildings. Energy Build 2007;39:335-42.

[29] Defraeye T, Blocken B, Carmeliet J. CFD analysis of convective heat transfer at the surfaces of a cube immersed in a turbulent boundary layer. Int J Heat Mass Transf 2010;53:297-308.

[30] Defraeye T, Blocken B, Carmeliet J. Convective heat transfer coefficients for exterior building surfaces: Existing correlations and CFD modelling. Energy Convers Manag 2011;52:512-22.

[31] Liu J, Srebric J, Yu N. Numerical simulation of convective heat transfer coefficients at the external surfaces of building arrays immersed in a turbulent boundary layer. Int J Heat Mass Transf 2013;61:209-25.

[32] Blocken B. 50 years of Computational Wind Engineering: Past, present and future. J Wind Eng Ind Aerodyn 2014;129:69-102.

[33] Meroney RN. Studying the convective heat transfer from a building model with infrared camera techniques, ASME Winter Annual Meeting, December 10-15, San Francisco, California, May, 28 p, ASME Paper 78-WA/HT-58.; 1978.

[34] Meinders ER. Experimental study of heat transfer in turbulent flows over wall mounted cubes. PhD thesis. Technische Universiteit Delft, 1998.

[35] Blocken B, Carmeliet J. A review of wind-driven rain research in building science. J Wind Eng Ind Aerodyn 2004;92:1079-130.

[36] Franke J, Hellsten A, Schlünzen H, Carissimo B. Best practice guideline for the CFD simulation of flows in the urban environment. COST action 732: quality assurance and improvement of microscale meteorological models. 2007.

[37] Tominaga Y, Mochida A, Yoshie R, Kataoka H, Nozu T, Yoshikawa M, et al. AIJ guidelines for practical applications of CFD to pedestrian wind environment around buildings. J Wind Eng Ind Aerodyn 2008;96:1749-61.

[38] Blocken B. Computational Fluid Dynamics for urban physics: Importance, scales, possibilities, limitations and ten tips and tricks towards accurate and reliable simulations. Build Environ 2015.

[39] Blocken B, Carmeliet J, Stathopoulos T. CFD evaluation of wind speed conditions in passages between parallel buildings - effect of wall-function roughness modifications for the atmospheric boundary layer flow. J Wind Eng Ind Aerodyn 2007;95:941-62.

[40] Blocken B, Stathopoulos T, Carmeliet J. CFD simulation of the atmospheric boundary layer: wall function problems. Atmos Environ 2007;41:238-52.

[41] Van Hooff T, Blocken B. Coupled urban wind flow and indoor natural ventilation modelling on a high-resolution grid: A case study for the Amsterdam ArenA stadium. Environ Model Softw 2010;25:51-65.

[42] Fox RW, McDonald AT, Pritchard PJ. Introduction to fluid mechanics. vol. 2. John Wiley \& Sons New York; 1998.

[43] Ansys Inc. Ansys fluent 12.0 - theory guide. USA: Lebanon; 2009.

[44] Shih T-H, Liou WW, Shabbir A, Yang Z, Zhu J. A new k- $€$ eddy viscosity model for high reynolds number turbulent flows. Comput Fluids 1995;24:227-38. 
[45] Wolfshtein M. The velocity and temperature distribution in one-dimensional flow with turbulence augmentation and pressure gradient. Int J Heat Mass Transf 1969;12:301-18.

[46] Murakami S. Comparison of various turbulence models applied to a bluff body. J Wind Eng Ind Aerodyn 1993;46:2136.

[47] Rodi W. Comparison of LES and RANS calculations of the flow around bluff bodies. J Wind Eng Ind Aerodyn 1997;69:55-75.

[48] Tominaga Y, Mochida A, Murakami S, Sawaki S. Comparison of various revised k- $\varepsilon$ models and LES applied to flow around a high-rise building model with 1: 1:2 shape placed within the surface boundary layer. J Wind Eng Ind Aerodyn 2008;96:389-411.

[49] Richards PJ, Hoxey RP. Appropriate boundary conditions for computational wind engineering models using the k- $\epsilon$ turbulence model. J Wind Eng Ind Aerodyn 1993;46:145-53.

[50] Wieringa J. Updating the Davenport roughness classification. J Wind Eng Ind Aerodyn 1992;41:357-68.

[51] Montazeri H, Blocken B. CFD simulation of wind-induced pressure coefficients on buildings with and without balconies: validation and sensitivity analysis. Build Environ 2013;60:137-49.

[52] Blocken B, Dezsö G, van Beeck J, Carmeliet J. Comparison of calculation models for wind-driven rain deposition on building facades. Atmos Environ 2010;44:1714-25.

[53] Montazeri H, Blocken B, Janssen WD, van Hooff T. CFD evaluation of new second-skin facade concept for wind comfort on building balconies: Case study for the Park Tower in Antwerp. Build Environ 2013;68:179-92. 

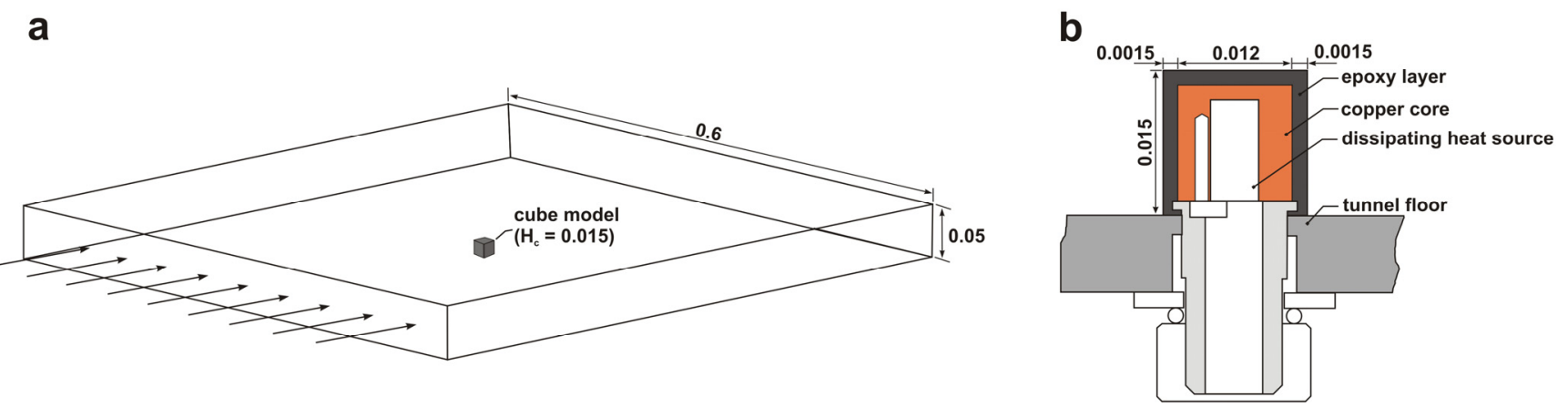

Figure 1. Experimental setup of Meinders et al. [22,23]: (a) Perspective view of cube model in channel. (b) Section through the heated cube. All dimensions are in meter.
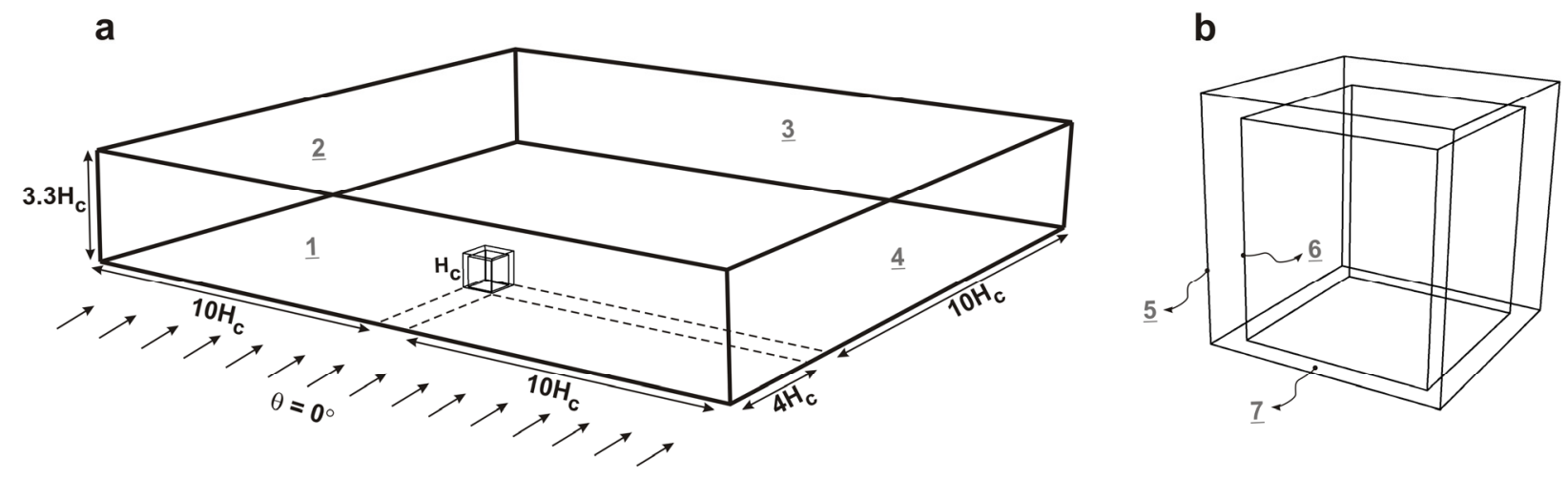

Figure 2. Perspective view of (a) computational domain and (b) model of cube including epoxy layer. 
a

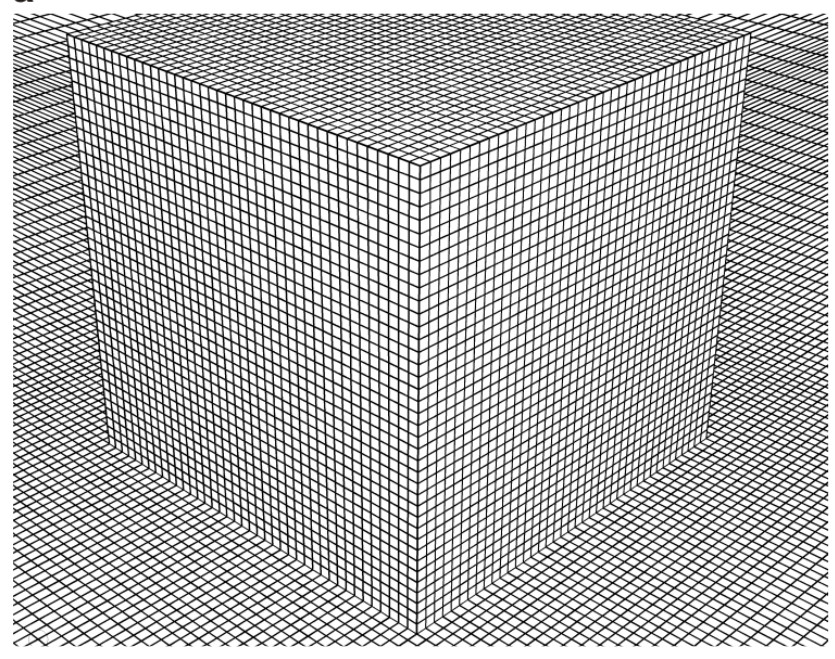

b

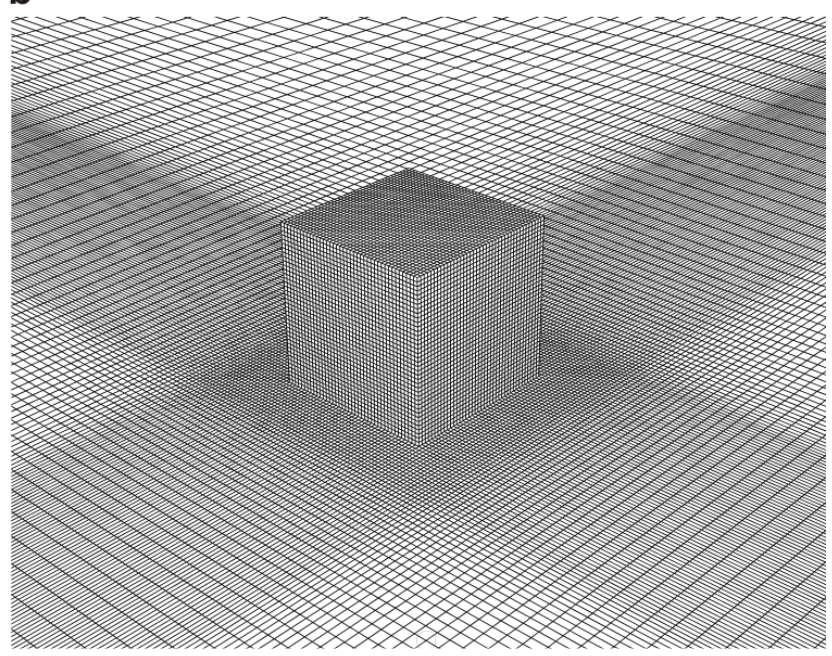

Figure 3. High-resolution computational grid (a) at cube and (b) part of the ground surface (total number of cells: $(2,180,960)$.
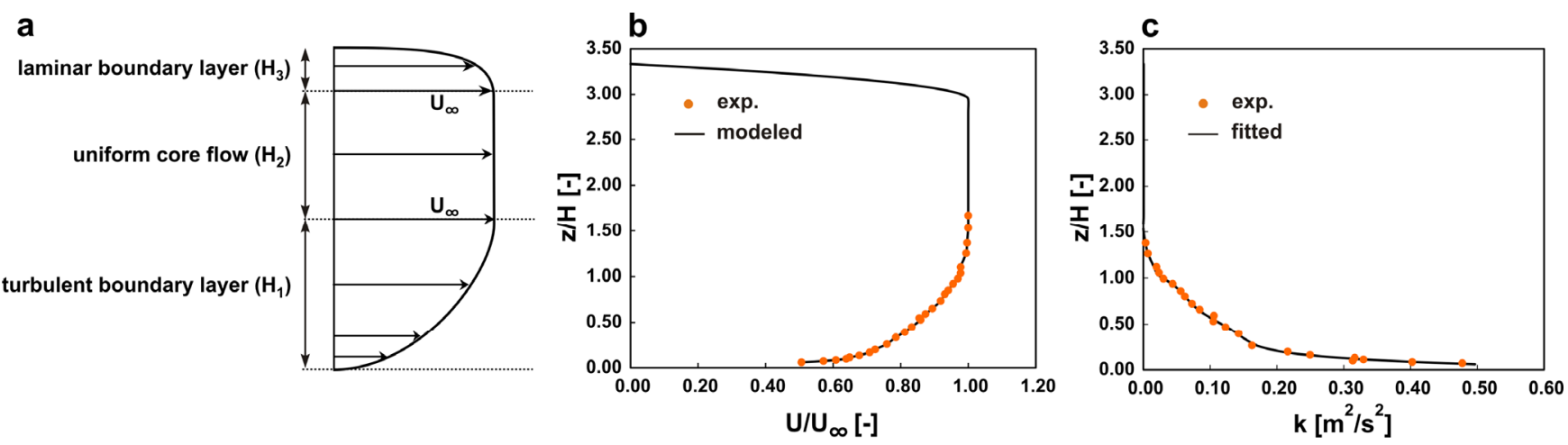

Figure 4. (a) Schematic and (b) measured (dots) and modelled (solid line) vertical profile of normalized mean wind velocity. (c) Measured (dots) and modelled (solid line) vertical profile of turbulent kinetic energy $\mathrm{k}$. 


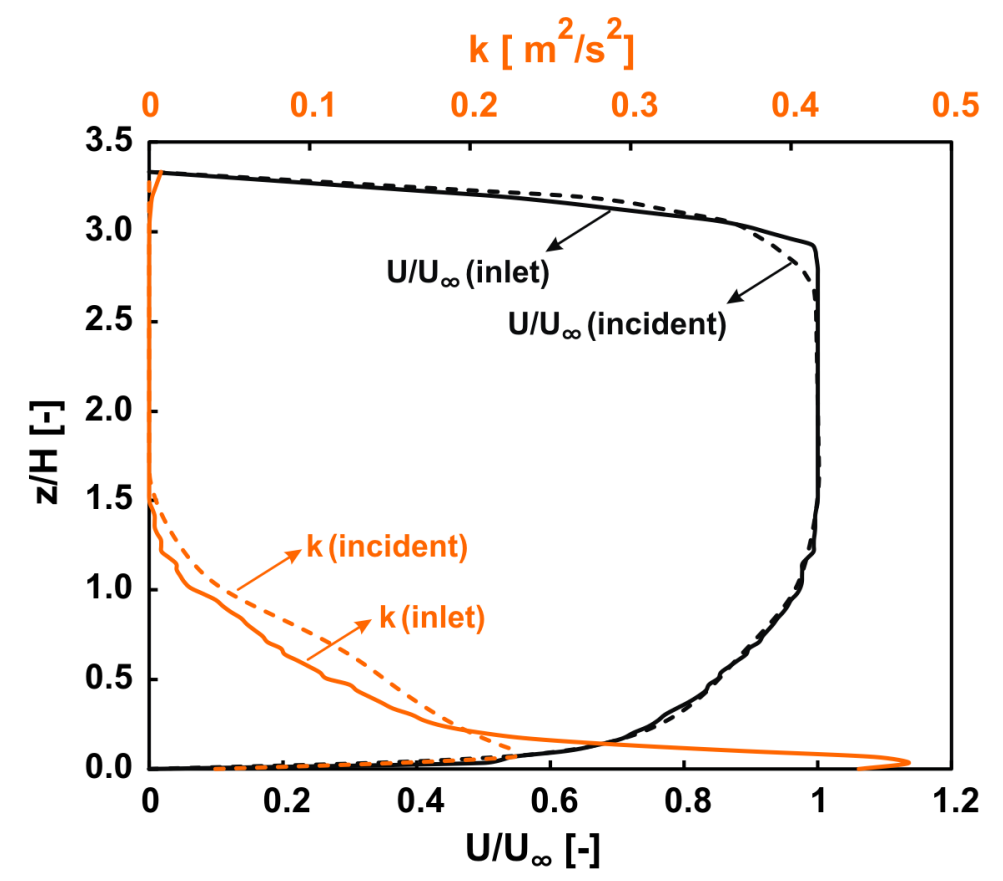

Figure 5. Comparison of inlet and incident vertical profiles of normalized wind speed $\mathrm{U} / \mathrm{U}_{\infty}$ and turbulent kinetic energy k.
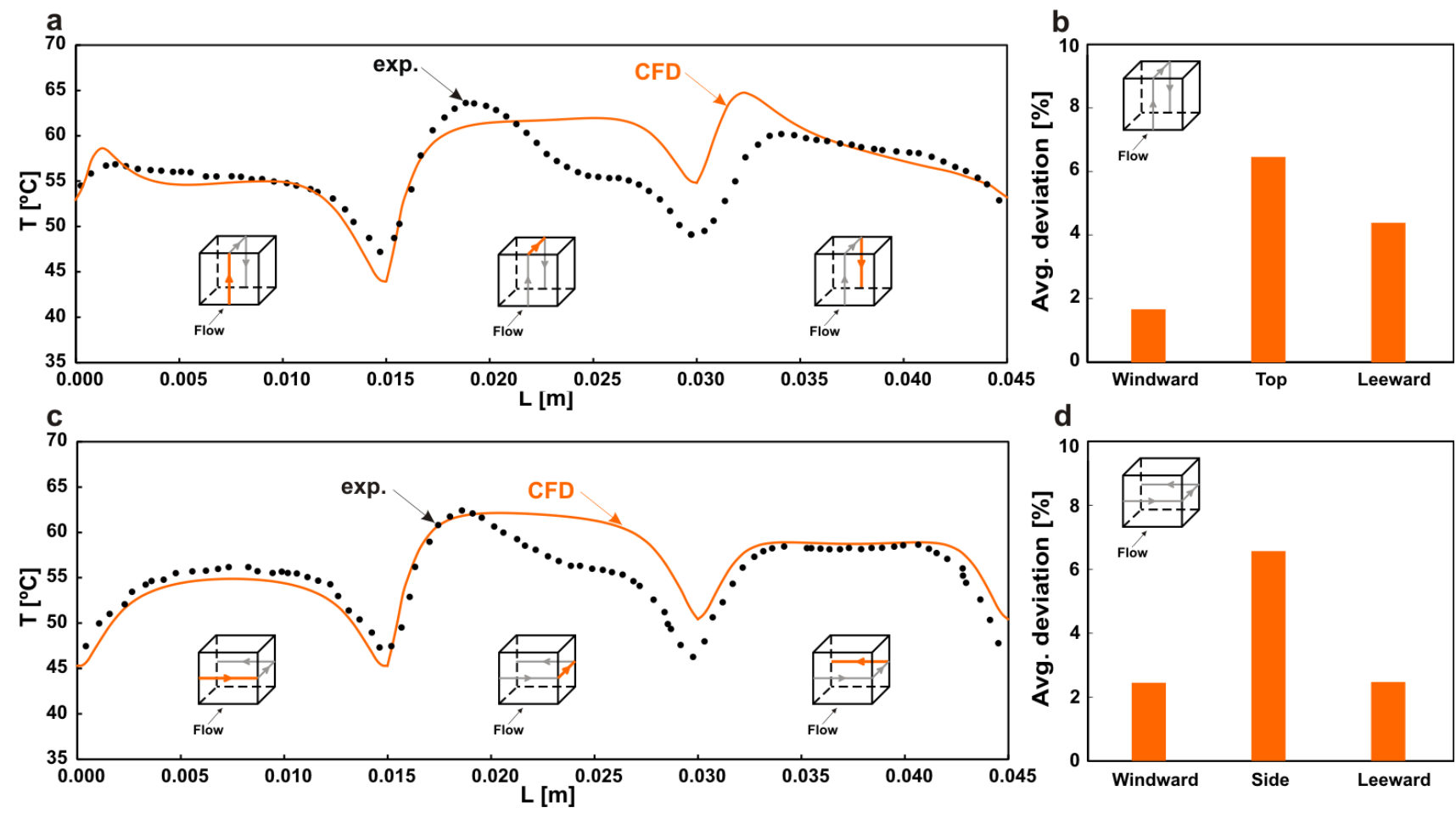

Figure 6. (a and c) Comparison of simulated and measured surface temperature along lines on the cube surfaces. (b and d) Average difference between simulations and measurements along same lines. 

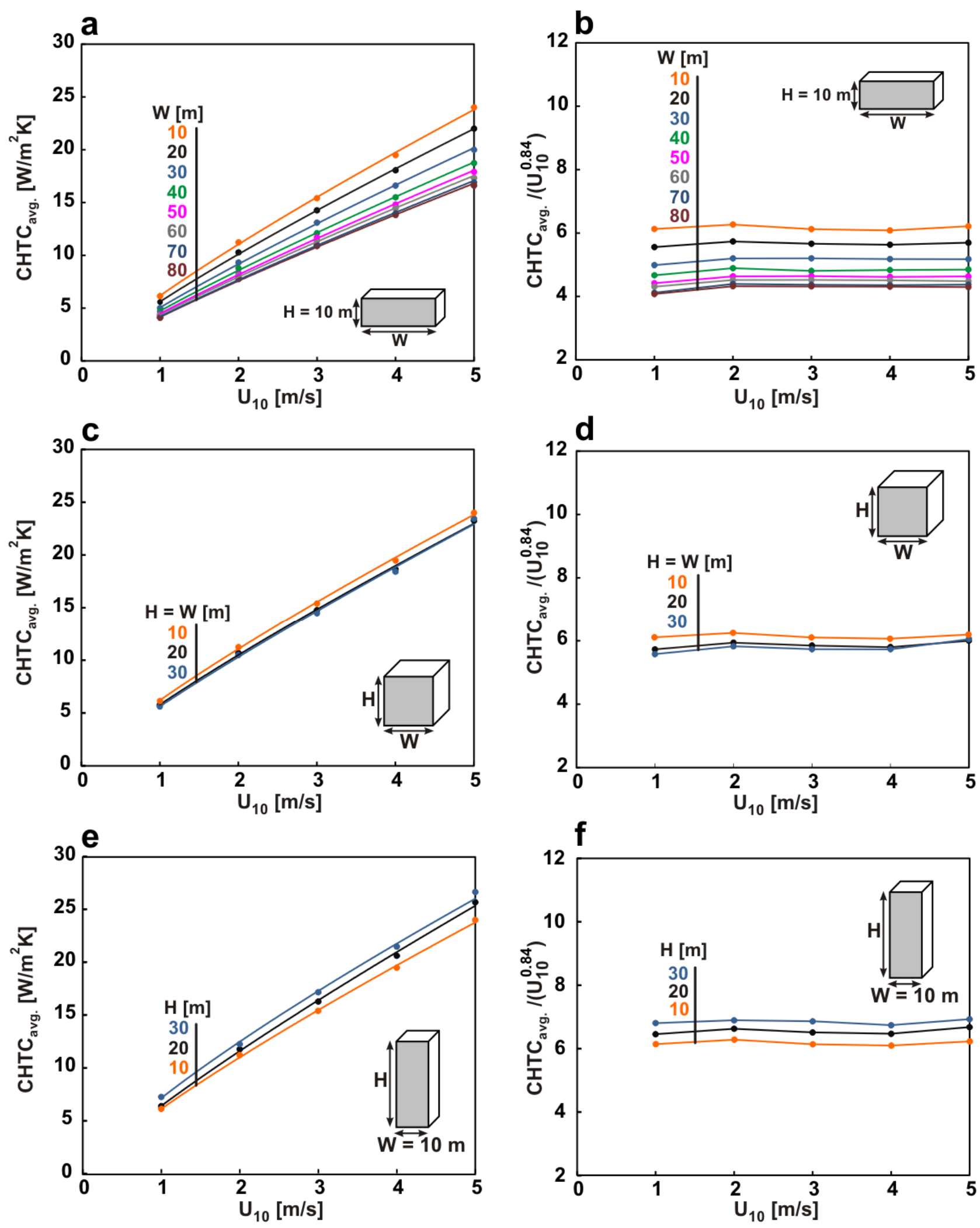

Figure 7. Profiles of surface-averaged $\mathrm{CHTC}\left(\mathrm{CHTC}_{\mathrm{avg}}\right)$ on the windward facade, as a function of $\mathrm{U}_{10}$, for buildings with (a) $\mathrm{H} \leq \mathrm{W}$, (c) $\mathrm{H}=\mathrm{W}$ and (e) $\mathrm{H} \geq \mathrm{W}$. (b,d,f) Same for $\mathrm{CHTC}_{\text {avg }} / \mathrm{U}_{10}^{0.84}$. 


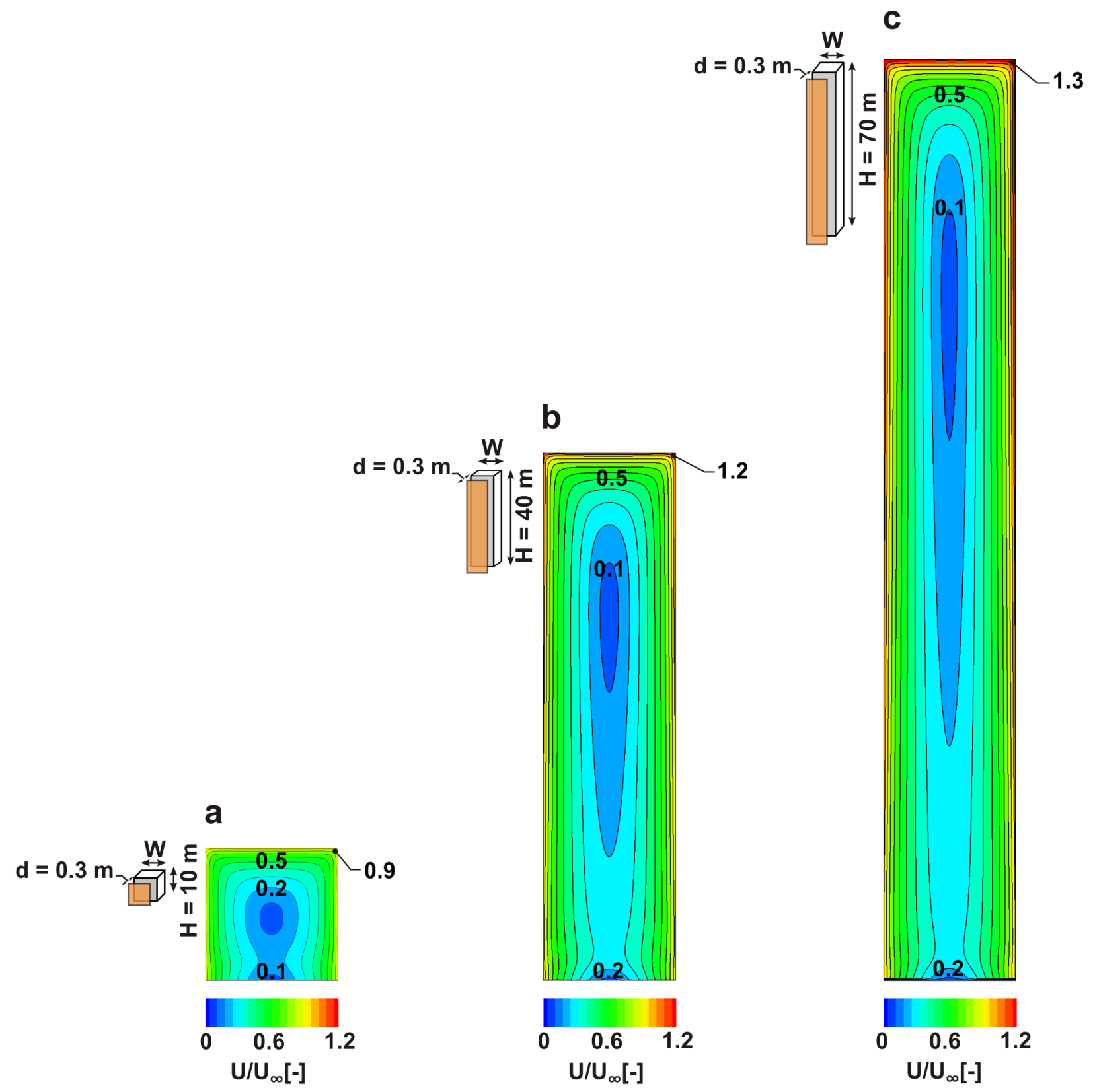

Figure 8. Distribution of normalized wind speed across a vertical plane at a distance $d=0.3 \mathrm{~m}$ from the windward facade for buildings with $\mathrm{W}=10 \mathrm{~m}$ and (a) $\mathrm{H}=10 \mathrm{~m}$, (b) $\mathrm{H}=40 \mathrm{~m}$ and (c) $\mathrm{H}=70 \mathrm{~m}$ (D=20 m for all cases). 
C

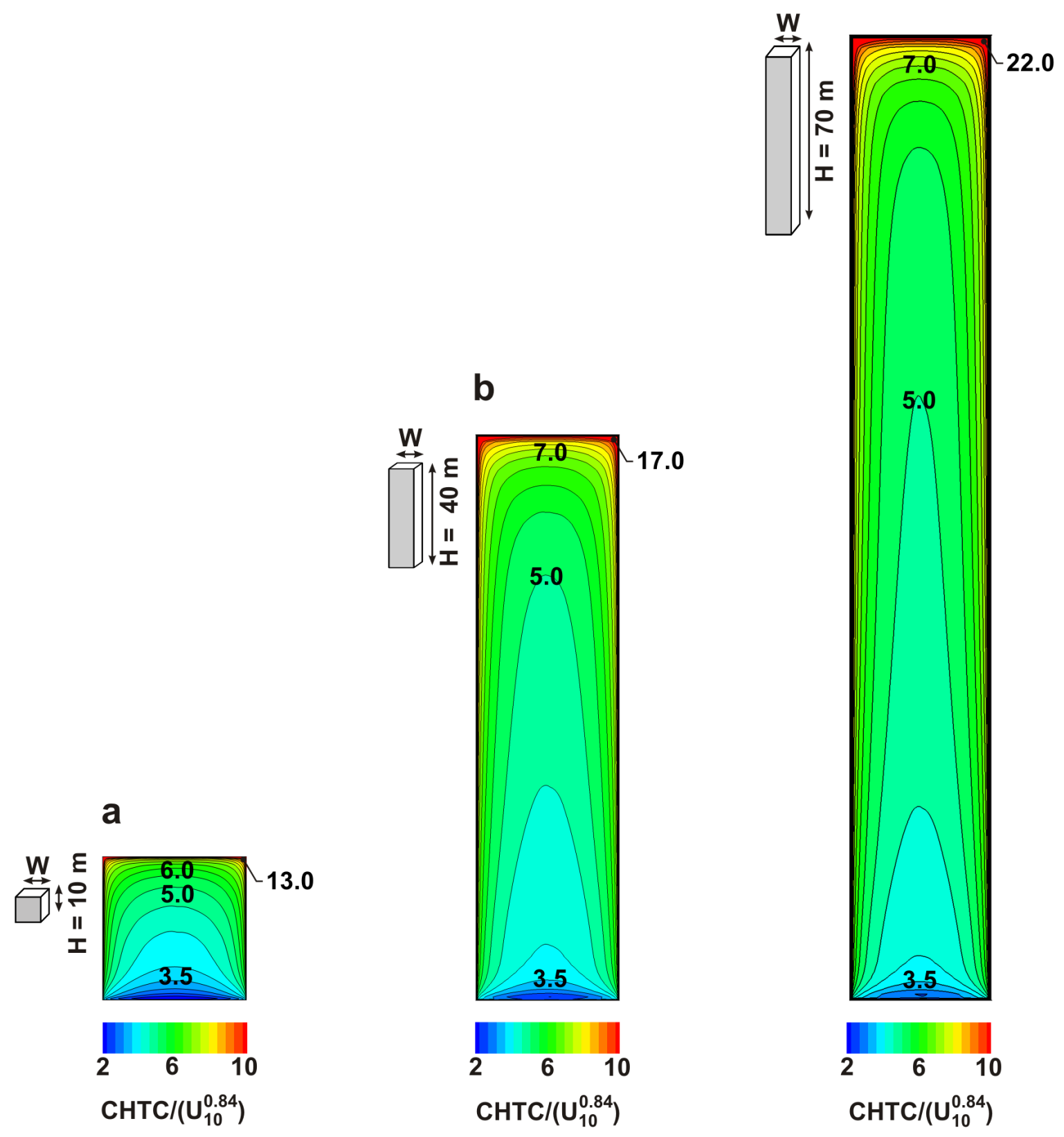

Figure 9. Distribution of $\mathrm{CHTC} /\left(\mathrm{U}_{10}^{0.84}\right)$ across the windward facade for buildings with $\mathrm{W}=10 \mathrm{~m}$ and (a) $\mathrm{H}=10 \mathrm{~m}$, (b) $\mathrm{H}=$ $40 \mathrm{~m}$ and (c) $\mathrm{H}=70 \mathrm{~m}(\mathrm{D}=20 \mathrm{~m}$ for all cases). 


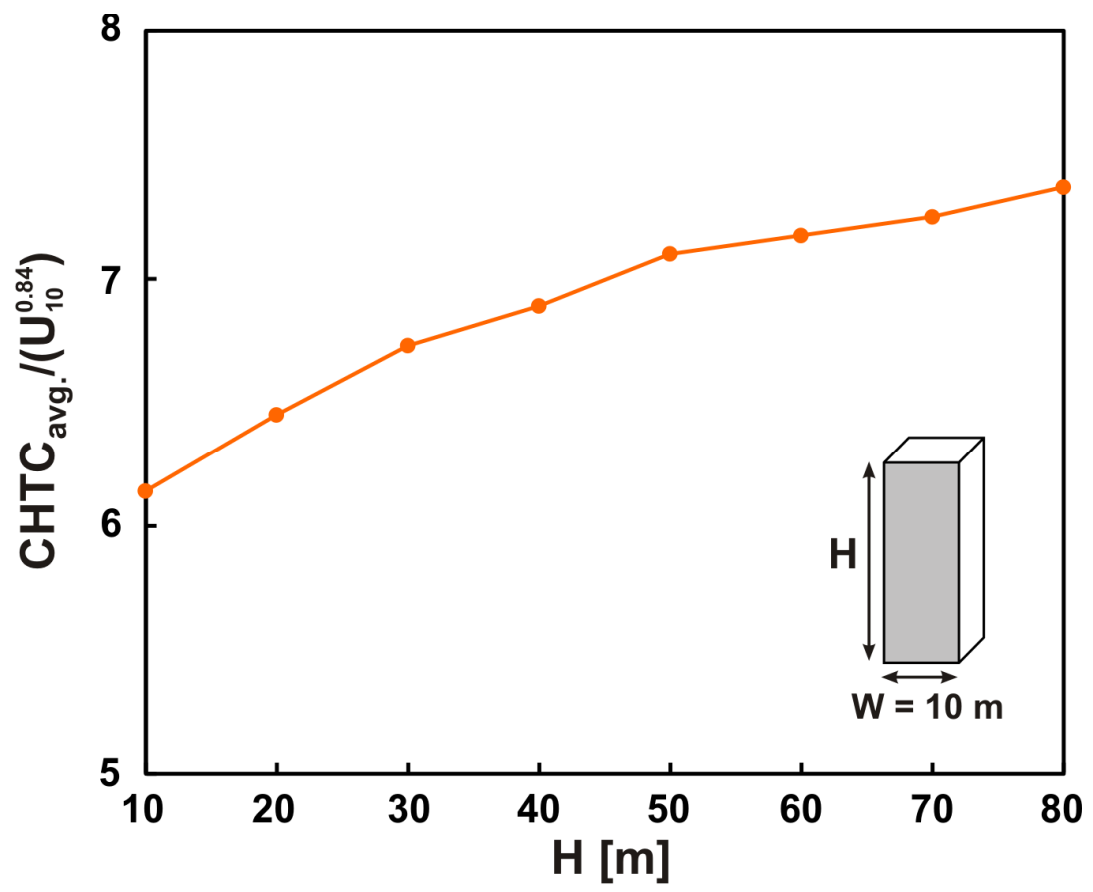

Figure 10. Profile of surface-averaged $\mathrm{CHTC} /\left(\mathrm{U}_{10}^{0.84}\right)$ on the windward facade for buildings with $\mathrm{W}=10 \mathrm{~m}$ and different values of $\mathrm{H}(\mathrm{D}=20 \mathrm{~m}$ for all cases $)$.
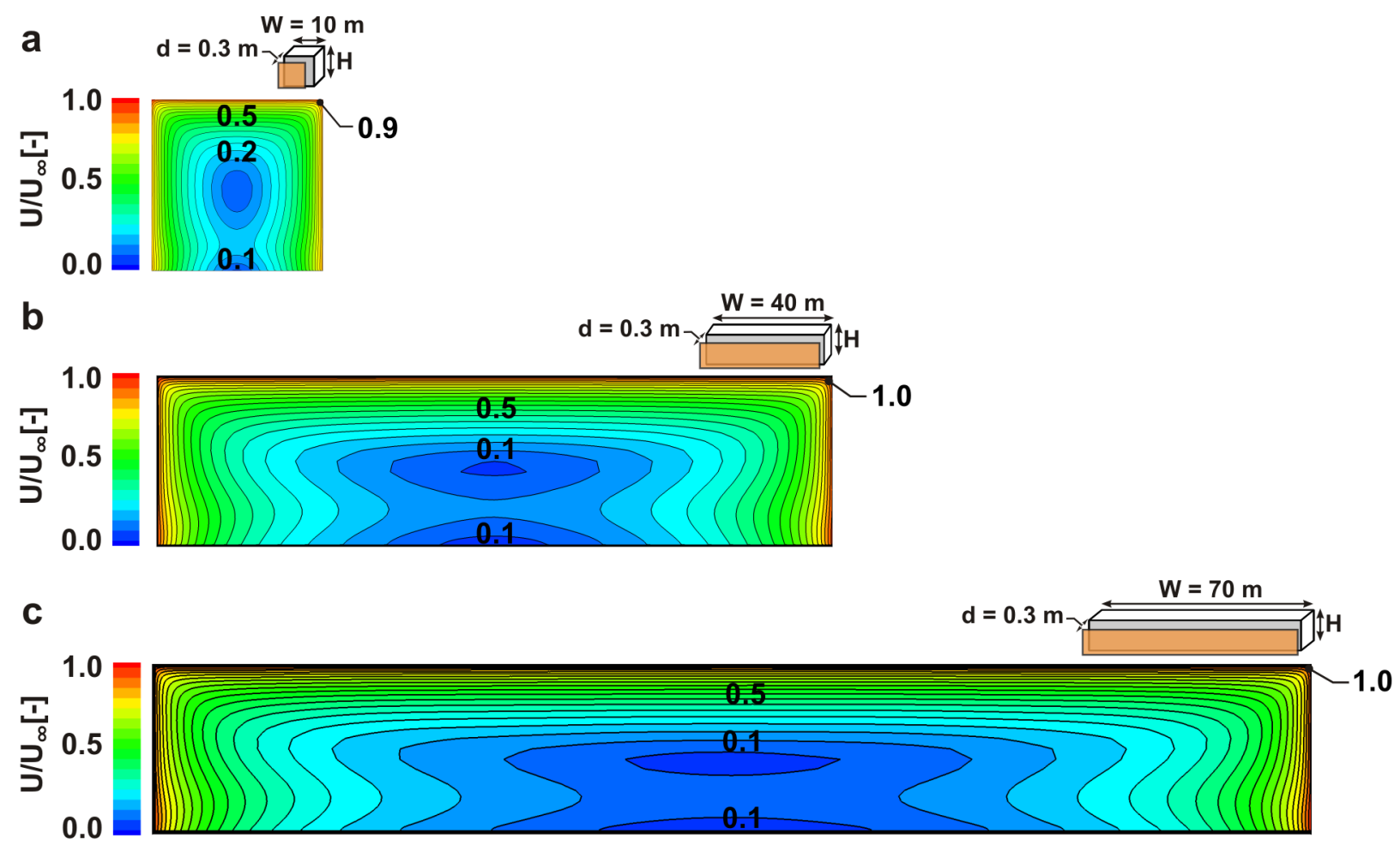

Figure 11. Distribution of normalized wind speed across a vertical plane at a distance $d=0.3 \mathrm{~m}$ from the windward facade for buildings with $\mathrm{H}=10 \mathrm{~m}$ and (a) $\mathrm{W}=10 \mathrm{~m}$, (b) $\mathrm{W}=40 \mathrm{~m}$ and (c) $\mathrm{W}=70 \mathrm{~m}$ (D=20 m for all cases). 


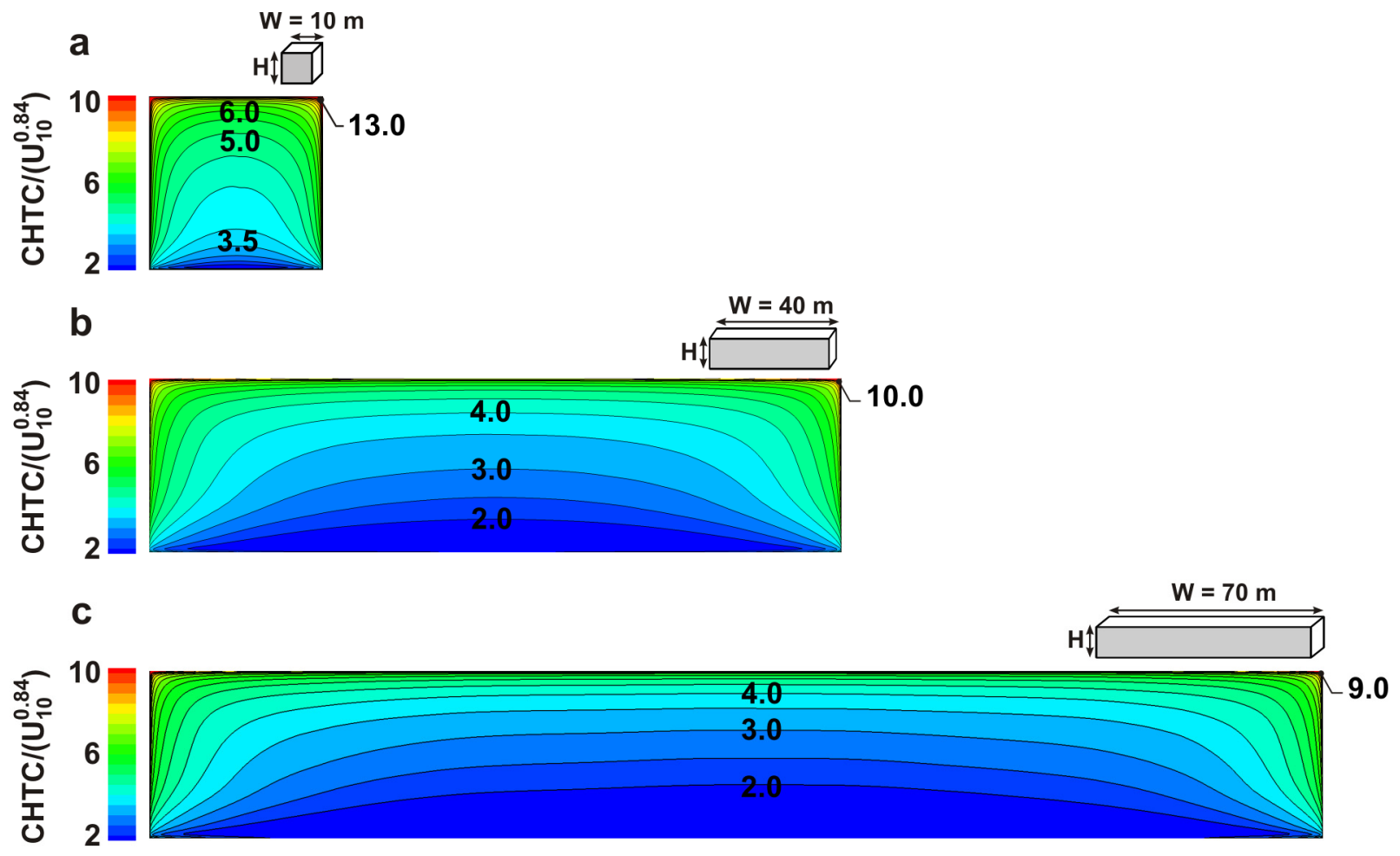

Figure 12. Distribution of CHTC/( $\left.\mathrm{U}_{10}^{0.84}\right)$ across the windward facade for buildings with $\mathrm{H}=10 \mathrm{~m}$ and (a) W=10 $\mathrm{m}$, (b) W $=40 \mathrm{~m}$ and $(\mathrm{c}) \mathrm{W}=70 \mathrm{~m}(\mathrm{D}=20 \mathrm{~m}$ for all cases $)$.

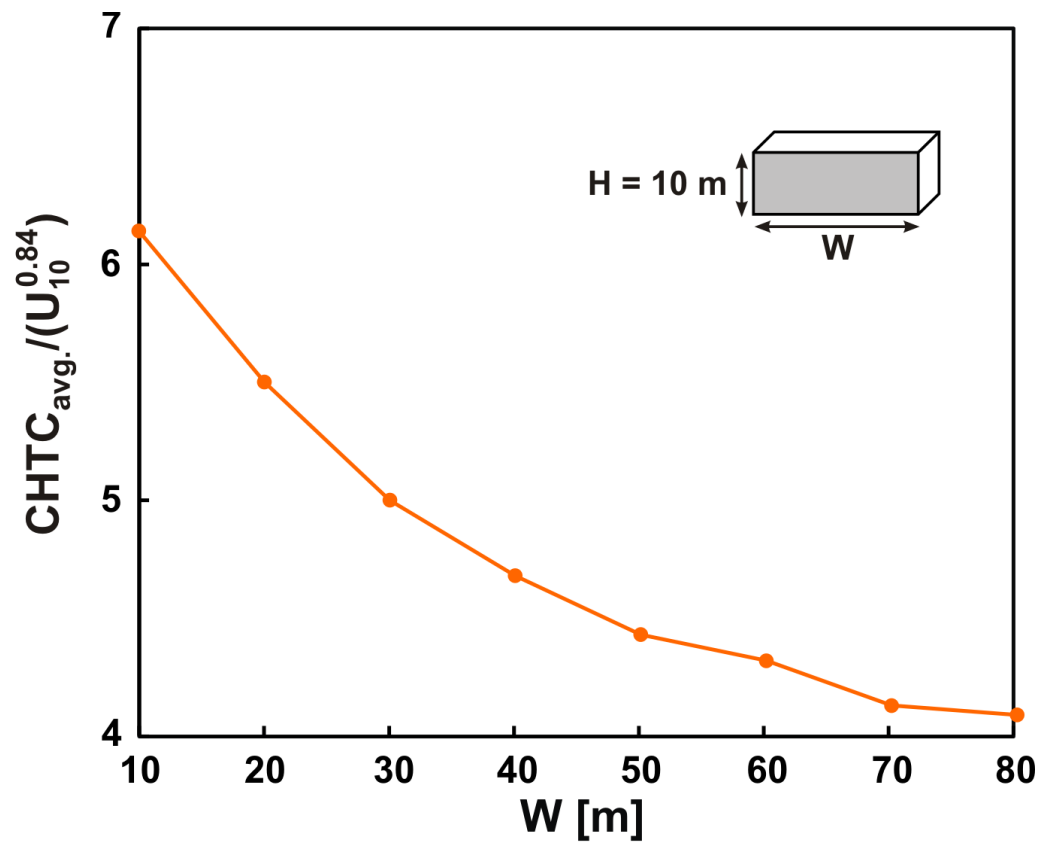

Figure 13. Profile of surface-averaged $\mathrm{CHTC} /\left(\mathrm{U}_{10}^{0.84}\right)$ on the windward facade for buildings with $\mathrm{H}=10 \mathrm{~m}$ and different values of $\mathrm{W}(\mathrm{D}=20 \mathrm{~m}$ for all cases $)$. 


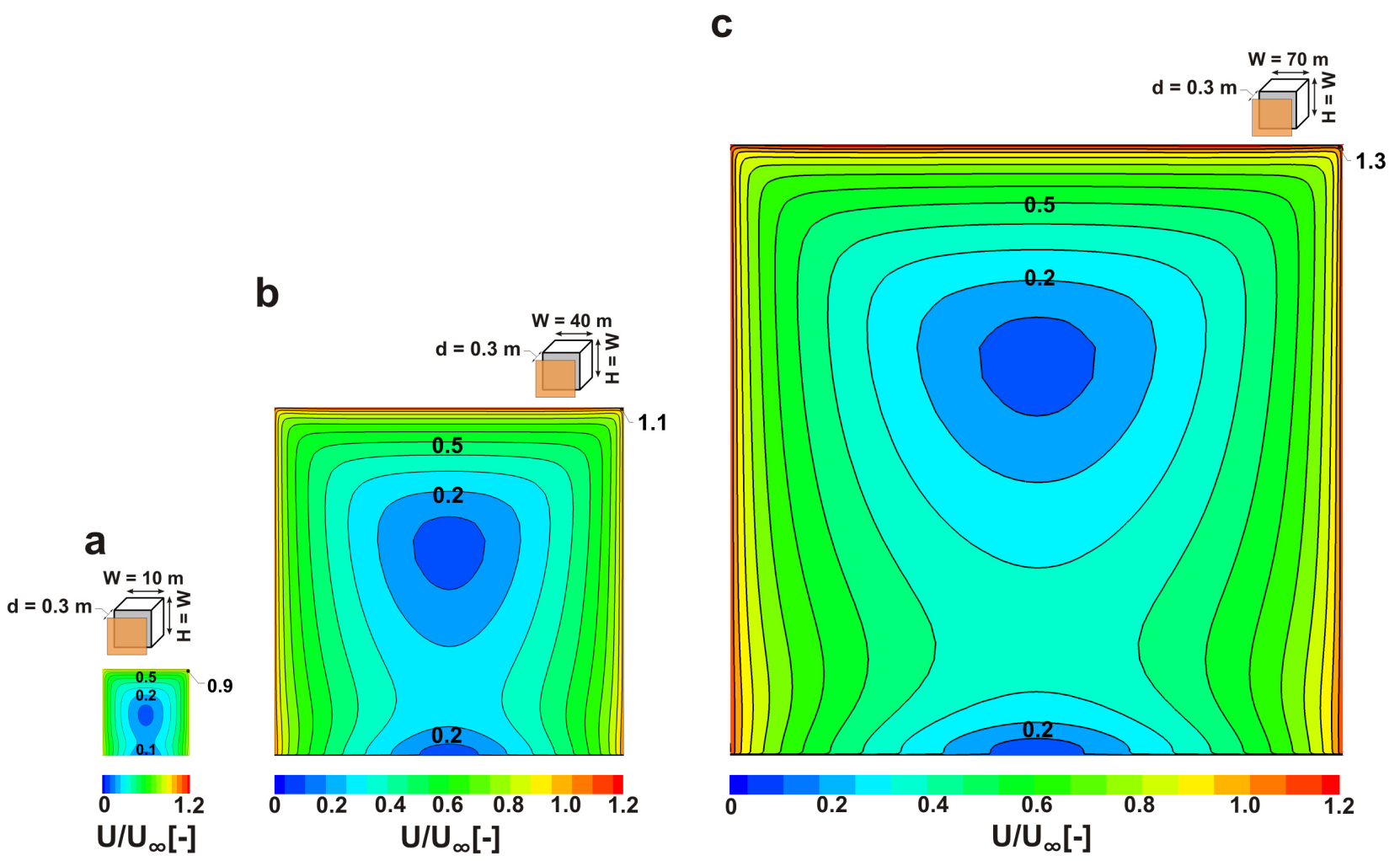

Figure 14. Distribution of normalized wind speed across a vertical plane at a distance $d=0.3 \mathrm{~m}$ from the windward facade for buildings with $\mathrm{H}=\mathrm{W}$ (square windward facade): (a) $\mathrm{H}=10 \mathrm{~m}$, (b) $\mathrm{H}=40 \mathrm{~m}$ and (c) $\mathrm{H}=70 \mathrm{~m}$ ( $\mathrm{D}=20 \mathrm{~m}$ for all cases).

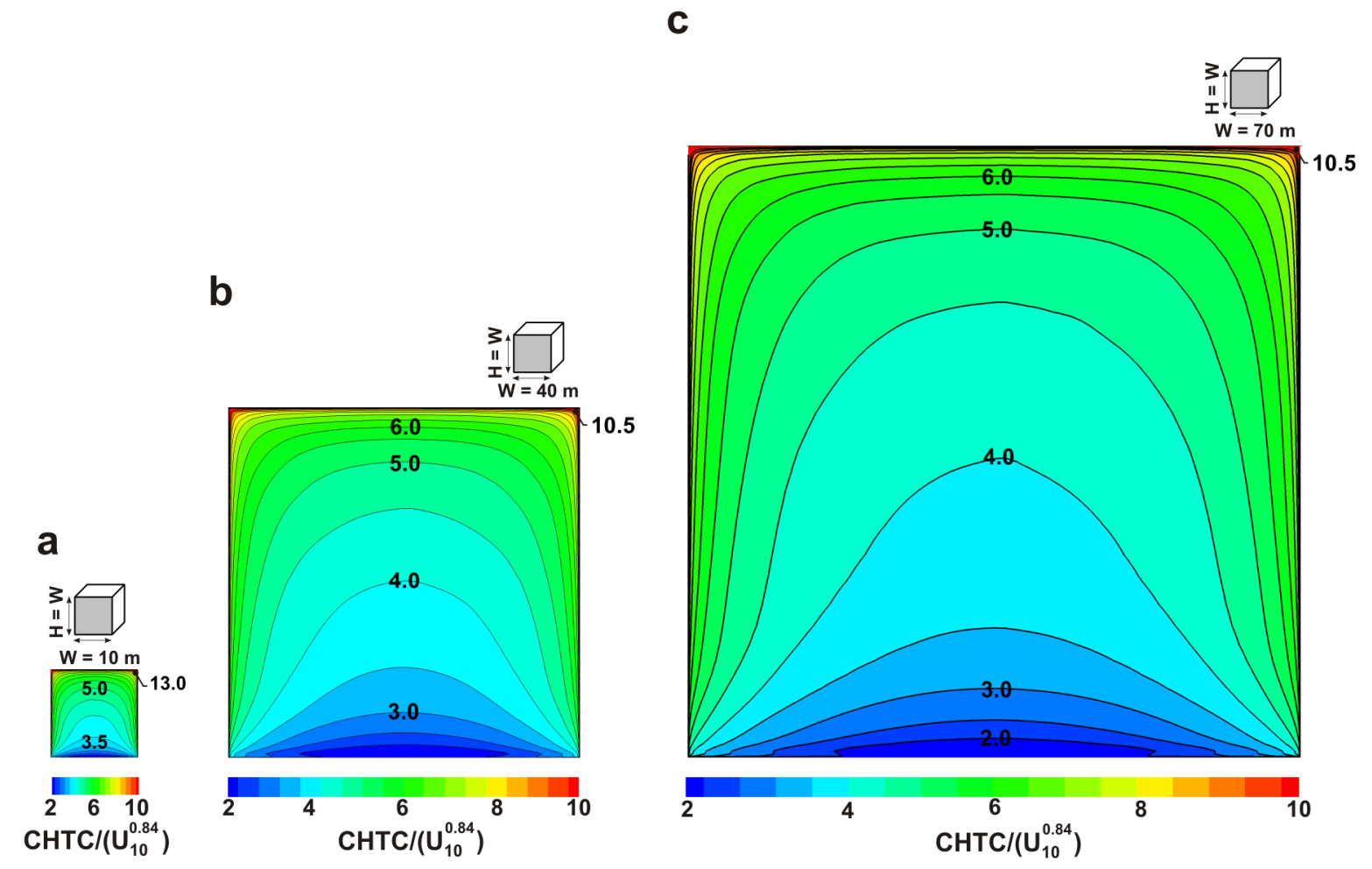

Figure 15. Distribution of $\mathrm{CHTC} /\left(\mathrm{U}_{10}^{0.84}\right)$ across the windward facade for buildings with $\mathrm{H}=\mathrm{W}$ (square windward facade): (a) $\mathrm{H}=10 \mathrm{~m}$, (b) $\mathrm{H}=40 \mathrm{~m}$ and (c) $\mathrm{H}=70 \mathrm{~m}$ ( $\mathrm{D}=20 \mathrm{~m}$ for all cases). 

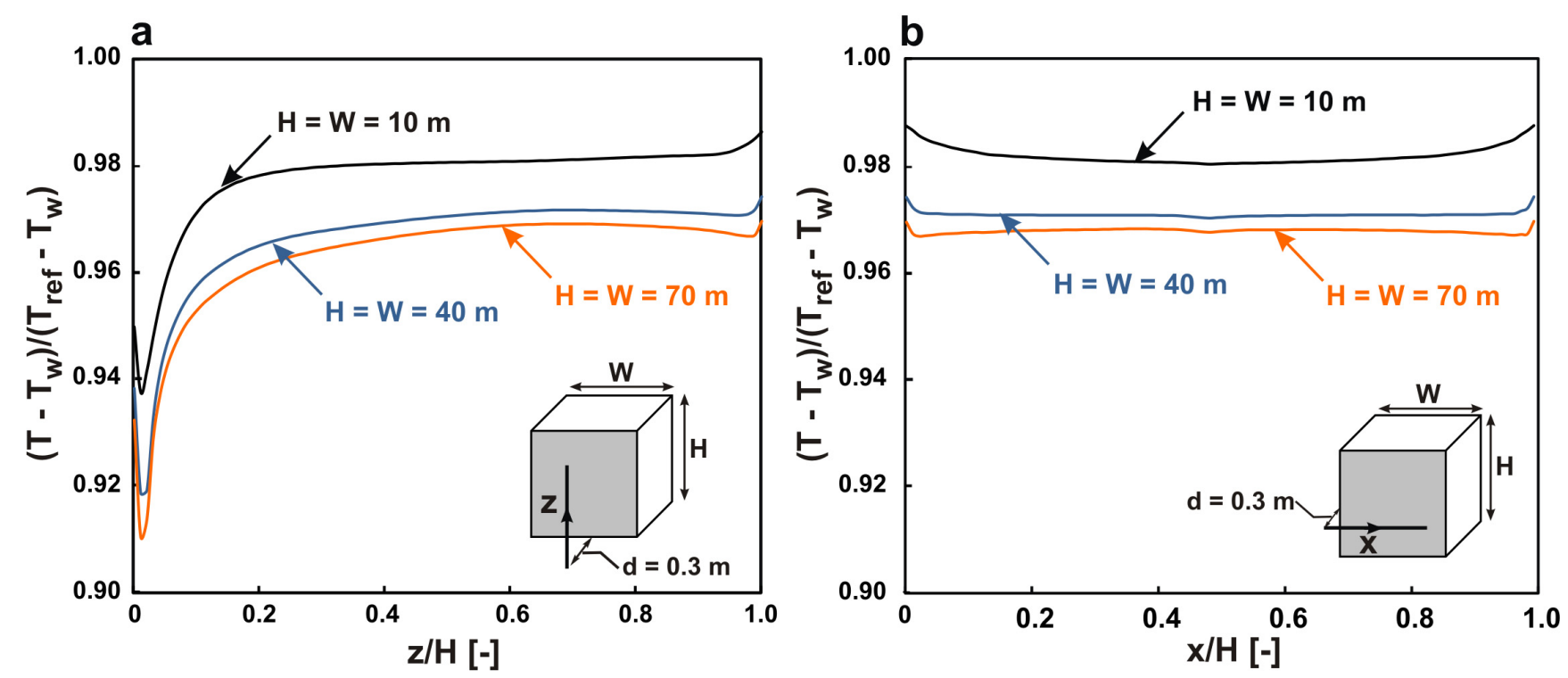

Figure 16. Normalized air temperature for different values of $\mathrm{H}(=\mathrm{W})$ along (a) vertical and (b) horizontal lines at a distance $\mathrm{d}=0.3 \mathrm{~m}$ from the windward facade.

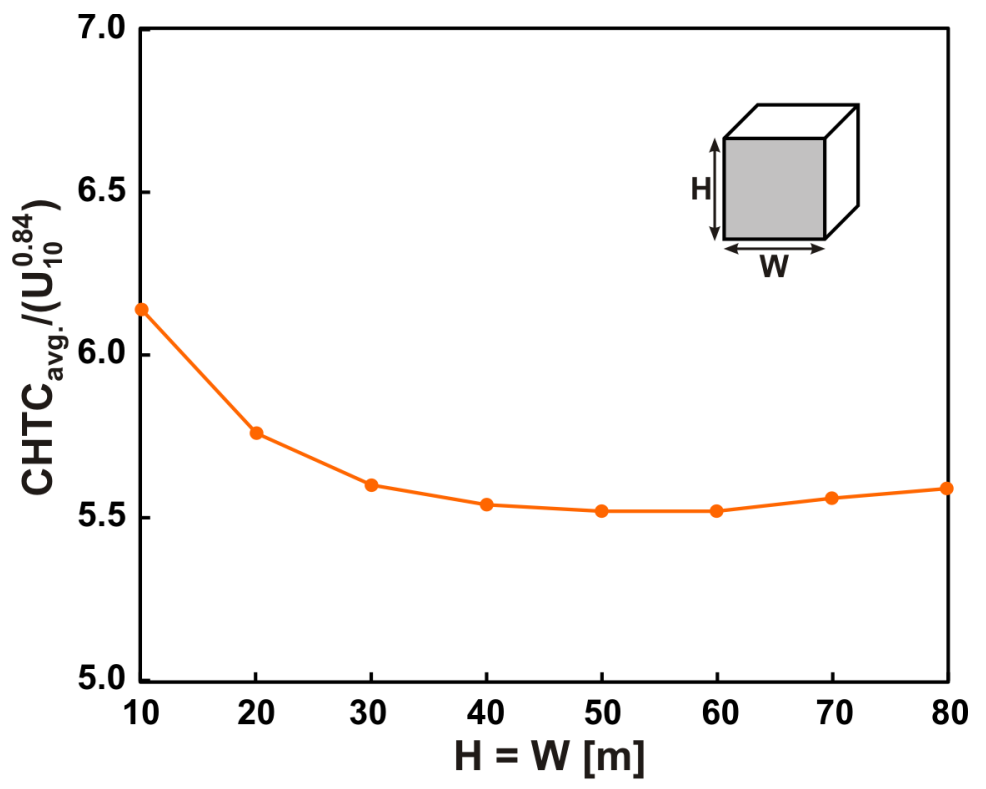

Figure 17. Profile of surface-averaged $\mathrm{CHTC} /\left(\mathrm{U}_{10}^{0.84}\right)$ on the windward facade for buildings with $\mathrm{H}=\mathrm{W}$ (square windward facade) $(\mathrm{D}=20 \mathrm{~m}$ for all cases $)$. 
Table 1. Geometry of three groups of buildings

\begin{tabular}{|c|c|c|c|c|}
\hline \multicolumn{2}{|c|}{ Building geometry } & $\begin{array}{l}\text { Height } \\
\text { H (m) }\end{array}$ & $\begin{array}{l}\text { Width } \\
\text { W (m) }\end{array}$ & $\begin{array}{l}\text { Depth } \\
\text { D (m) }\end{array}$ \\
\hline $\mathrm{H} \geq \mathrm{W}$ & $\mathrm{H}$ & $10,20,30,40,50,60,70,80$ & 10 & 20 \\
\hline $\mathrm{H} \leq \mathrm{W}$ & $\mathrm{H}=10 \mathrm{~m} \downarrow$ & 10 & $10,20,30,40,50,60,70,80$ & 20 \\
\hline $\mathrm{H}=\mathrm{W}$ & $\mathrm{H}$ & $10,20,30,40,50,60,70,80$ & $\mathrm{~W}=\mathrm{H}$ & 20 \\
\hline
\end{tabular}

Table 2. CFD-based correlations between surface-averaged CHTC for the windward facade and reference wind speed $\mathrm{U}_{10}$

\begin{tabular}{|c|c|c|c|c|c|c|c|c|c|}
\hline \multicolumn{2}{|c|}{ Building geometry } & \multicolumn{8}{|c|}{$\mathbf{W}[\mathbf{m}]$} \\
\hline & & 10 & 20 & 30 & 40 & 50 & 60 & 70 & 80 \\
\hline & CHTC & $6.17\left(\mathrm{U}_{10}\right)^{0.84}$ & $5.62\left(\mathrm{U}_{10}\right)^{0.84}$ & $5.05\left(\mathrm{U}_{10}\right)^{0.86}$ & $4.73\left(\mathrm{U}_{10}\right)^{0.85}$ & $4.48\left(\mathrm{U}_{10}\right)^{0.86}$ & $4.37\left(\mathrm{U}_{10}\right)^{0.86}$ & $4.19\left(\mathrm{U}_{10}\right)^{0.86}$ & $4.15\left(\mathrm{U}_{10}\right)^{0.86}$ \\
\hline & $\mathrm{R}^{2}$ & 0.9995 & 0.9997 & 0.9996 & 0.9994 & 0.9995 & 0.9994 & 0.9991 & 0.9992 \\
\hline \multicolumn{2}{|c|}{ Building geometry } & & $\mathbf{H}[\mathbf{m}]$ & & & & & & \\
\hline & & 10 & 20 & 30 & & & & & \\
\hline $\mathrm{H}$ & CHTC & $6.17\left(\mathrm{U}_{10}\right)^{0.84}$ & $6.47\left(\mathrm{U}_{10}\right)^{0.84}$ & $7.22\left(\mathrm{U}_{10}\right)^{0.82}$ & & & & & \\
\hline$w=10 \mathrm{~m}$ & $\mathrm{R}^{2}$ & 0.9995 & 0.9994 & 0.9988 & & & & & \\
\hline \multicolumn{2}{|c|}{ Building geometry } & \multicolumn{3}{|c|}{$\mathbf{H}=\mathbf{W}[\mathbf{m}]$} & & & & & \\
\hline \multirow{3}{*}{$\mathrm{H}$} & & 10 & 20 & 30 & & & & & \\
\hline & CHTC & $6.17\left(\mathrm{U}_{10}\right)^{0.84}$ & $5.79\left(\mathrm{U}_{10}\right)^{0.85}$ & $5.62\left(\mathrm{U}_{10}\right)^{0.87}$ & & & & & \\
\hline & $\mathrm{R}^{2}$ & 0.9995 & 0.9993 & 0.9988 & & & & & \\
\hline
\end{tabular}


Table 3. Surface-averaged CHTC- $\mathrm{U}_{10}$ correlations from CFD simulations

\begin{tabular}{|c|c|c|c|c|}
\hline Ref. & $\begin{array}{l}\text { Building Geometry } \\
\mathrm{H} \times \mathbf{W} \times \mathbf{D}(\mathrm{m})\end{array}$ & $\begin{array}{l}\text { near-wall region } \\
\text { modelling }\end{array}$ & $\begin{array}{l}U_{10} \text { range } \\
(\mathrm{m} / \mathrm{s})\end{array}$ & $\begin{array}{l}\text { CHTC-U } U_{10} \text { correlation } \\
\text { for windward }\end{array}$ \\
\hline Emmel et al. [18] & $2.7 \times 6 \times 8$ & Wall function & $1.0-15.0$ & $C H T C=5.15 U_{10}^{0.81}$ \\
\hline Blocken et al. [17] & $10 \times 10 \times 10$ & $\begin{array}{l}\text { Low-Reynolds } \\
\text { number modelling }\end{array}$ & $1.0-4.0$ & $C H T C=4.60 U_{10}^{0.89}$ \\
\hline Defraeye et al. [19] & $10 \times 10 \times 10$ & $\begin{array}{l}\text { Low-Reynolds } \\
\text { number modelling }\end{array}$ & $0.50-5.0$ & $C H T C=5.15 U_{10}^{0.82}$ \\
\hline Defraeye et al. [20] & $10 \times 10 \times 10$ & $\begin{array}{l}\text { Low-Reynolds } \\
\text { number modelling }\end{array}$ & $0.15-7.50$ & $C H T C=5.01 U_{10}^{0.85}$ \\
\hline
\end{tabular}

